\title{
Site U1396
}

\author{
Expedition 340 Scientists $^{2}$
}

\section{Chapter contents}

Background and objectives.......... 1

Operations..................

Lithostratigraphy..............

Paleontology and biostratigraphy .......4

Geochemistry ................6

Physical properties .............

Paleomagnetism ............. 8

References................. 9

Figures.................... 11

Tables...................... 27

${ }^{1}$ Expedition 340 Scientists, 2013. Site U1396. In Le Friant, A., Ishizuka, O., Stroncik, N.A., and the Expedition 340 Scientists, Proc. IODP, 340: Tokyo (Integrated Ocean Drilling Program Management International, Inc.).

doi:10.2204/iodp.proc.340.106.2013

'Expedition 340 Scientists' addresses.

\section{Background and objectives}

Integrated Ocean Drilling Program (IODP) Site U1396 (proposed Site CARI-01C; $16^{\circ} 30.49^{\prime} \mathrm{N}, 62^{\circ} 27.10^{\prime} \mathrm{W} ; 801$ meters below sea level [mbsl]) is the most western site drilled during Expedition 340 (Fig. F1).

The bathymetric survey for Site U1396 revealed a region bounded by a topographic high to the north and by two large canyons to the south. Site survey data indicated that this site could penetrate regular (unperturbed) seismic reflectors. The drill site is located on the topographic high to minimize any perturbations (e.g., related to turbidites). Site U1396 is located in the same area as the $5.75 \mathrm{~m}$ long CAR-MON 2 core taken during the Caraval cruise in 2002. Sediment recovered in the CAR-MON 2 core provides a stratigraphic record extending back $\sim 250$ k.y., as shown by $\delta^{18} \mathrm{O}$ chronostratigraphy. The calculated sedimentation rate (including tephra) is $\sim 2.3 \mathrm{~cm} / \mathrm{k}$.y. (Le Friant et al., 2008). The recovered core also contained material from several explosive Plinian eruptions, which had not previously been identified on land (Le Friant et al., 2008).

The objective for Site U1396 was to characterize the eruptive history of Montserrat. Volcanism started on Montserrat at $2.6 \mathrm{Ma}$ at Silver Hills and moved to Centre Hills between 0.5 and $1.0 \mathrm{Ma}$, with the youngest volcanism being centered on the Soufrière HillsSouth Soufrière Hills complex ( 170 ka to present) (Harford et al., 2002). With conventional coring it is only possible to retrieve samples of recent volcanic activity. Drilling to a target depth of 132 meters below seafloor (mbsf) at Site U1396 was intended to extend our knowledge of the volcanic history of Montserrat to the birth of the island at at least $\sim 2.5$ Ma. Petrologic, lithologic, sedimentologic, and geochronologic analyses of volcanic rocks and volcaniclastic material from this site are expected to date as far back as $4 \mathrm{Ma}$ (assuming a sedimentation rate of $2.3 \mathrm{~cm} / \mathrm{k} . \mathrm{y}$. from the CAR-MON 2 study) and will provide significant new constraints on the early development of volcanism on Montserrat and on the spatial and temporal distribution of volcanic activity.

\section{Operations}

\section{Transit to Site U1396}

After a $28.6 \mathrm{nmi}$ transit from Site U1395 in cruise mode, the vessel arrived at Site U1396. The vessel stabilized over Site U1396 at 
$2245 \mathrm{~h}$ on 16 March 2012. All times reported in this volume are given in ship local time, which was Universal Time Coordinated (UTC) $-4 \mathrm{~h}$. The position reference was a combination of GPS signals and a single acoustic beacon. The positioning beacon was deployed at $2310 \mathrm{~h}$ on 16 March. At the end of operations at Site U1396, the beacon was sent an acoustic command to release. The beacon was retrieved at $0730 \mathrm{~h}$ on 18 March.

\section{Site U1396}

Site U1396 consists of three holes (Table T1). The original plan called for two holes to a depth of $\sim 132$ mbsf. The first hole was successfully cored and was terminated at a total depth of 134.9 mbsf. Hole U1396B was a short hole designed to capture an interval in Hole U1396A that was poorly recovered because of a shattered core liner. Hole U1396C was cored to a depth of 139.4 mbsf. No logging was scheduled at Site U1396. The advanced piston corer (APC) was deployed 31 times. The cored interval with the APC was $283.8 \mathrm{~m}$ with a recovery of $296.38 \mathrm{~m}$ of core (104\%). Overall recovery for Site U1396 was 104\%. There was one drilled interval of $5 \mathrm{~m}$ in Hole U1396B. Total time spent on Site U1396 was $34.75 \mathrm{~h}$.

\section{Hole U1396A}

The vessel arrived at Site U1396 and was in position at $2245 \mathrm{~h}$ on 16 March 2012. After an uneventful pipe trip, the top drive was picked up and the bit was spaced out to spud Hole U1396A. The bit was initially set at 789 meters below rig floor (mbrf), and the core barrel was run in on wireline. The first attempt to recover the mudline came back without core. The bit was lowered to 795 mbrf for another attempt at a mudline core. The hole was spudded at $0345 \mathrm{~h}$ on 17 March. Seafloor depth was calculated from the length of the first core to be $798.9 \mathrm{mbrf}$ (787.4 mbsl). Orientation was performed with the FlexIt tool on the first 12 cores with good results. Nonmagnetic core barrels were used for APC coring for Cores 340-U1396A-1H through 12H. There was only one coring anomaly during the hole; Core $2 \mathrm{H}$ had the liner shatter when the piston fired. Advanced piston corer temperature tool (APCT-3) measurements were taken on Cores $3 \mathrm{H}$ through $6 \mathrm{H}$. There was only one partial stroke experienced in the entire piston coring sequence. A total of 15 piston cores were taken over a $134.9 \mathrm{~m}$ interval with a total recovery of $140.51 \mathrm{~m}$ of core $(104 \%)$. After the completion of APC coring, the drill string was pulled back with the top drive still installed, and the bit cleared the seafloor at $1615 \mathrm{~h}$ on $17 \mathrm{March}$, ending Hole U1396A. The total time spent on Hole U1396A was $17.5 \mathrm{~h}$.

\section{Hole U1396B}

After clearing the seafloor in Hole U1396A, the vessel was offset 20 m east and Hole U1396B was spudded at $1650 \mathrm{~h}$ on 17 March 2012. Seafloor depth was used from Hole U1396A, which was 798.9 mbrf (787.4 mbsl). The uppermost $5 \mathrm{~m}$ of Hole U1396B was drilled, and Core 340-U1396B-2H was shot from 5 mbsf. Both the FlexIt tool and nonmagnetic core barrels were used for Core $2 \mathrm{H}$. One piston core was taken over the $9.5 \mathrm{~m}$ interval, with a total recovery of $10.00 \mathrm{~m}$ of core. Overall recovery for Hole U1396B was $105 \%$. The hole was terminated after a single core, and the drill string was pulled clear of the seafloor at $1725 \mathrm{~h}$. The total time spent on Hole U1396B was $1.25 \mathrm{~h}$.

\section{Hole U1396C}

After clearing the seafloor in Hole U1396B, the vessel was offset $20 \mathrm{~m}$ south and Hole U1396C was spudded at $1810 \mathrm{~h}$ on 17 March 2012. Seafloor depth was calculated from the length of the first core $798.1 \mathrm{mbrf}$ (786.6 mbsl). Orientation was performed with the FlexIt tool on all 15 cores with good results. Nonmagnetic core barrels were used all cores. APCT-3 measurements were taken on Cores 340-U1396C-6H and $11 \mathrm{H}$. Microspheres were run on Cores $3 \mathrm{H}, 6 \mathrm{H}$, and $14 \mathrm{H}$. There was only one partial stroke in the entire piston coring sequence. Two of the cores $(11 \mathrm{H}$ and $12 \mathrm{H}$ ) had to be drilled over to release them from the formation. A total of 15 piston cores were taken over a $139.4 \mathrm{~m}$ interval with a total recovery of $145.92 \mathrm{~m}$ of core. Overall recovery for Hole U1396C was $105 \%$. After the completion of APC coring, the top drive was set back and the drill string was pulled back to the rig floor. Drilling equipment was secured on the rig floor at $0935 \mathrm{~h}$ on $18 \mathrm{March}$, ending Site U1396 and Hole U1396C. The total time spent on Hole U1396C was $16.0 \mathrm{~h}$. The vessel then proceeded underway to Site U1397.

\section{Lithostratigraphy}

Three holes were drilled at Site U1396. Holes U1396A and U1396C were drilled to 135.5 and $140.0 \mathrm{mbsf}$, respectively; Hole U1396B was only drilled to 15 mbsf. The aim of Hole U1396B was to fill out an interval of core that was poorly recovered (deformed during coring) in Hole U1396A.

This site mainly comprises a series of hemipelagic intervals and relatively thin (typically $<10 \mathrm{~cm}$ and most often $<5 \mathrm{~cm}$ ) tephra layers in Units B and E. A distinctive very coarse grained unit rich in white felsic clasts (Unit D) provides a good marker horizon in Holes U1396A and U1396C. Massive volcaniclastic sand intervals comprise the remaining Units A and C. 


\section{Distinguishing fallout deposits from fine-grained distal turbidites}

A key issue for the description of these deposits is to distinguish tephra layers deposited by fallout from eruption columns ("fallout deposits") from distal turbidity current deposits. Both types of deposit can be normally graded and lack laminations. The criteria adopted for Expedition 340 are given below.

Fallout deposits contain very little or no reworked carbonate material. However, the amount of carbonate material is difficult to determine accurately by visual examination in fine-grained sediment. Therefore, a limited number of microscopic component analyses (as time on board permitted) were undertaken to determine composition. Importantly, fallout deposits tend to be better sorted than turbidites because of settling processes; turbidites tend to have very poor sorting. Only turbidites will display evidence of strong lateral flow, such as basal erosion and reworking as bed-load. However, basal erosion can be hard to determine unambiguously in narrowdiameter core barrels and can be overprinted by core deformation (downward bowing of basal contacts). Ripple cross-lamination will also only occur in turbidites, but it was rarely if ever seen in Site U1396 cores. Care needs to be taken to distinguish planar lamination due to tractional reworking (turbidites) from grain size and compositional zoning (tephra fallout).

\section{Defining units}

The lithostratigraphy of Site U1396, thick sequences of thin tephra layers and intervening hemipelagic units, does not lend itself to defining obvious lithostratigraphic units. Information from magnetic susceptibility curves should be considered in future studies to better constrain the stratigraphic record. For example, the cores contain hemipelagic intervals with increased sand content or variable color, which may be bioturbated tephra layers. The average accumulation rate of $3 \mathrm{~cm} / \mathrm{k} . \mathrm{y}$. for Site U1396 means that thinner tephra layers are most likely reworked by burrowing organisms and seafloor currents.

\section{Unit A}

Depths: Hole U1396A = 0-0.4 mbsf, Hole U1396C = 0-0.4 mbsf

Unit A extends from 0 to 0.4 mbsf and comprises $39 \mathrm{~cm}$ of "soupy," high-water content, bioclast-rich fine sand, which is only seen in Holes U1396A and U1396C (Hole U1396B did not sample the interval directly below the seafloor). This sand is massive and ungraded, and it could represent a high-density turbidite.
It seems likely that this unit is related to the 1995recent eruption on Montserrat. The unit has an oxidized brown top and is unlikely to be an artifact of coring. A similar uppermost unit was not observed previously in other piston and gravity cores in the vicinity of Site U1396 (Le Friant et al., 2008; Cassidy et al., submitted).

\section{Unit B}

Depths: Hole U1396A $=0.4-116.1 \mathrm{mbsf}$, Hole $\mathrm{U} 1396 \mathrm{~B}=5-14.5 \mathrm{mbsf}$, Hole U1396C $=0.4-$ $116.1 \mathrm{mbsf}$

Unit B extends from 0.4 to 116.1 mbsf and comprises a thick sequence of interbedded hemipelagic mud and tephra layers, with the latter typically being $<5 \mathrm{~cm}$ and rarely $>10 \mathrm{~cm}$ in thickness. In general, hemipelagic mud makes up most of Unit B. Tephra layers become more common below 90-95 mbsf, as seen in the magnetic susceptibility data. Hemipelagic mud dominates the middle part of the unit.

Thin black or brown fine sand and silt layers (typically $<5 \mathrm{~cm}$ thick) are common in Unit B and most likely represent fallout deposits. In some cases their coarse grain size (and well-sorted nature) and exclusively volcaniclastic composition is strong evidence for fallout. There may be many more cryptotephras, which are not visible upon visual examination, within the hemipelagic mud intervals.

Most cores at this site comprise hemipelagic mud and thin tephras, with the only exceptions being a few thick tephra layers that are described in more detail below.

\section{Thick tephra layers}

Tephra units thicker than $12 \mathrm{~cm}$ are observed in only a few instances:

- Upper $5 \mathrm{~m}$ : the uppermost part of Unit B (only seen in Hole U1396A) has two thick $(20-30 \mathrm{~cm})$ poorly sorted sand layers with a mixed bioclastic (20\%-50\%) and volcaniclastic (50\%-80\%) composition at 1.7 and 2.6 mbsf. These mixed composition units are most likely turbidites. Sandwiched within the lower unit is a well-sorted layer comprising 99\% volcanic material that is a few centimeters thick and is most likely a fallout unit. Together with a $4 \mathrm{~cm}$ (fallout) tephra layer at $3.7 \mathrm{mbsf}$, these tephra layers occur within the uppermost 5.7 mbsf. Similarly thick tephra layers are not apparent in the $5.7 \mathrm{~m}$ long CAR-MON 2 core studied by Le Friant et al. (2008) that extends to $250 \mathrm{ka}$, suggesting these thick tephras have a localized distribution. The CAR-MON 2 core was located $\sim 15 \mathrm{~km}$ from Site U1396, nearer to Montserrat on the same bathymetric ridge. The two 
thick sand layers seen in the upper $5.7 \mathrm{~m}$ of Hole U1396A may be correlative to the more subtle cryptotephras described by Le Friant et al. (2008).

- Two 12-15 cm mixed bioclastic-volcaniclastic poorly sorted turbidites occur in Hole U1396C at 11.2 and 10.2 mbsf.

- A $~ 50 \mathrm{~cm}$ well-sorted coarse fallout unit occurs at 34.3 mbsf in Hole U1396A and comprises at least two graded sequences.

- A $24 \mathrm{~cm}$ thick dark coarse tephra layer occurs at 48.7 mbsf in Hole U1396C.

- A $22 \mathrm{~cm}$ thick well-sorted fallout deposit occurs at 82.7 mbsf in Hole U1396A and may be equivalent to a $14 \mathrm{~cm}$ layer at $78.5 \mathrm{mbsf}$ in Hole U1396C or a $35 \mathrm{~cm}$ thick layer at $84.4 \mathrm{mbsf}$ in Hole U1396C.

- Three coarser units occur near the base of the unit in Hole U1396A. A distinctive $50 \mathrm{~cm}$ thick, dark gray, massive, poorly sorted medium sand occurs at 106.7 mbsf and is most likely a volcaniclastic turbidite.

- In Hole U1396A a $12 \mathrm{~cm}$ thick, coarse, well-sorted fallout unit occurs at $111.4 \mathrm{mbsf}$, and a $35 \mathrm{~cm}$ thick well-sorted fallout deposit occurs at 115.2 mbsf.

\section{Isolated pebble-sized volcanic clasts}

Individual outsize volcanic clasts $(\leq 1 \mathrm{~cm})$ are observed in the hemipelagic mud in a few locations. Their origin (perhaps as reworked dropstones) is poorly understood at present.

\section{Inclined laminated sandstone}

A $14 \mathrm{~cm}$ interval of fine to medium sand is seen in Hole U1396C at 110.7 mbsf; the interval has inclined and truncated laminations that are enigmatic.

\section{Unit C}

Depths: Hole U1396A $=116.1-122$ mbsf, Hole $\mathrm{U} 1396 \mathrm{C}=116.1-122 \mathrm{mbsf}$

Unit C extends from 116.1 to 122 mbsf in Holes U1396A and U1396C and comprises massive medium-coarse volcaniclastic sand. The sand has $\sim 85 \%$ light-colored andesitic lava grains within a finer darker matrix made mainly of mineral crystals. The sand hue changes progressively vertically, and these changes in hue represent compositional zoning. Unit $\mathrm{C}$ is darker than the overlying and underlying units and has some dispersed $1 \mathrm{~cm}$ clasts near its base. Unit $\mathrm{C}$ may represent high-density turbidity current deposition.

Unit $\mathrm{C}$ is absent or poorly developed in Hole U1396A and was too deep for Hole U1396B. Preliminary comparison of the core logs does not indicate an obvious correlative unit in Hole U1396A at a similar depth below seafloor. If Unit $C$ does not represent sand sucked in during APC coring (i.e., it is not an artifact of drilling), this is surprising, as Holes $\mathrm{U} 1396 \mathrm{~A}$ and $\mathrm{U} 1396 \mathrm{C}$ are separated by just $28 \mathrm{~m}$.

\section{Unit D}

Depths: Hole U1396A $=122-123.9$ mbsf, Hole $\mathrm{U} 1396 \mathrm{C}=122-123.9 \mathrm{mbsf}$

Unit D extends from 122 to 123.9 mbsf. This unit comprises a distinctive series of unusually coarse (commonly as large as centimeter-scale clasts) breccias with a pinkish color (Fig. F2). Five stacked finingupward units make up Unit D in Holes U1396A and U1396C, with the uppermost unit being the thickest. The uppermost unit has very well sorted intervals of pebble-sized $(\leq 2 \mathrm{~cm})$ material, with little or no sand or mud-sized matrix material. These normally graded intervals are 3-62 $\mathrm{cm}$ thick and separated by thin (1$5 \mathrm{~cm}$ ) layers of massive fine sand or silt. Unit D is similar in thickness and grading in Holes U1396A and U1396C. The similar stratigraphy beneath Unit $\mathrm{D}$ in both holes suggests it has not eroded underlying strata, which is consistent with air fall deposition.

\section{Unit E}

Depths: Hole U1396A = 123.9-135.5 (bottom of hole), Hole U1396C = 123.9-140 mbsf (bottom of hole)

Unit $\mathrm{E}$ extends from 123.9 mbsf to the base of Hole U1396C at 140 mbsf. This unit comprises hemipelagic mud and relatively abundant thin $(<10 \mathrm{~cm})$ tephra layers. Many of these tephra layers are wellsorted and this is consistent with fallout deposition.

\section{Paleontology and biostratigraphy}

Core catcher samples at Site U1396 contain calcareous nannofossils and planktonic and benthic foraminifers of varying abundances and at varying levels of preservation. Preservation deteriorates with depth; however, it remains adequate for confident biostratigraphic age assignment. Both nannofossil and planktonic foraminiferal biostratigraphic data and magnetostratigraphic dates for Site U1396 indicate ages ranging from late Pleistocene to early Pliocene (Fig. F3). Sedimentation rate appears to increase with depth (see "Paleomagnetism" for further discussion). Sponge spicules and ostracods are scarce and generally moderately preserved. Pteropods and heteropods were not found in any core catcher samples. 


\section{Calcareous nannofossils}

Nannofossil preservation was good to moderate throughout the 13 core catcher samples analyzed from Hole U1396A (of 15 collected), one sample from Hole U1396B, and 13 samples from Hole U1396C (of 15 collected). The remaining core catcher samples were not analyzed because of the coarse nature of the material collected.

Sample 340-U1396A-1H-CC contains abundant Gephyrocapsa caribbeanica, common Helicosphaera hyalina, and small forms $(2.5-3 \mu \mathrm{m})$ that may be Emiliania huxleyi. The presence of E. huxleyi was further substantiated by the absence of Pseudoemiliania lacunosa. Thus, this sample lies within the E. huxleyi Zone (Zone CN15; Okada and Bukry, 1980). The age of this sample is younger than 0.25 Ma (Kameo and Bralower, 2000).

Samples 340-U1396A-2H-CC to 4H-CC yielded a variety of small Gephyrocapsa species, P. lacunosa, and Crenalithus doronicoides. The latter species defines Zone CN13 (Okada and Bukry, 1980). G. caribbeanica is abundant throughout these three core catcher samples; therefore, these samples are within Subzone CN13b (Okada and Bukry, 1980). Moreover, Calcidiscus macintyrei is common in Sample 340-U1396A-4H-CC. Gartner (1977) has used this species to divide the Quaternary. Herein, Gartner's methodology has been followed using the revised zonation for this sample. Sample 340-U1396A-4H-CC lies within Subzone CN13b (Okada and Bukry, 1980) or the C. macintyrei Zone (Gartner, 1977). Overall preservation is good to moderate.

Sample 340-U1396A-5H-CC yielded a characteristic Pliocene assemblage with abundant Discoaster brouweri and common C. macintyrei. The $D$. brouweri are extremely affected by overgrowth; however, identification was possible. Otherwise, the sample contained abundant specimens with good preservation. $C$. macintyrei and D. brouweri are indicative of an upper Pliocene assemblage, placing this sample within Subzone CN12d. Sample 340-U1396A-6H-CC contains an abundant and well-preserved Pliocene assemblage with Discoaster surculus, D. brouweri, C. macintyrei, and Hayaster perplexus. Generally, Discoaster species were well preserved in comparison to Sample 340U1396A-5H-CC. Because of the absence of Discoaster tamalis, Sample 340-U1396A-6H-CC was placed within Subzone CN12b (Okada and Bukry, 1980). Samples 340-U1396A-7H-CC to 10H-CC yielded a characteristic lower Pliocene assemblage with a variety of Discoaster species. D. pentaradiatus, D. surculus, D. brouweri, Discoaster asymmetricus, and D. tamalis are common. Discoaster variabilis and Discoaster challengeri are generally less abundant (few to none). The preservation, especially of Discoaster specimens, in this sample is good except for Ceratolithus rugosus, which is heavily overgrown, destroying the general morphology. Because neither Sphenolithus abies/ neoabies nor Reticulofenestra pseudoumbilica were detected, this sample was assigned to Subzone CN12a.

Samples 340-U1396A-11H-CC to $15 \mathrm{H}-\mathrm{CC}$ contain $S$. abies/neoabies and $R$. pseudoumbilica, which indicate lower Pliocene Subzone CN11a.

In Hole U1396B, zones, subzones, and ages similar to those in Hole U1396A were identified. The top core catcher samples are placed in the Quaternary, whereas the bottom samples (340-U1396B-6H-CC to 15H-CC) show trends similar to those in Hole U1396A, indicating an age of late to early Pliocene. Hole U1396B recovered only one core catcher sample (340U1396B-2H-CC), which yielded an upper Pleistocene assemblage with G. caribbeanica, G. oceanica, and $H$. hyalina. Sample 340-U1396B-2H-CC was assigned to Subzone CN14a (Okada and Bukry, 1980).

\section{Planktonic foraminifers}

All 31 core catcher samples from Site U1396 were analyzed for foraminiferal content. Only two samples, 340-U1396C-1H-CC and 2H-CC, did not suggest a reliable age because they lacked marker taxa. Three samples, 340-U1396A-12H-CC and 13H-CC and 340U1396C-13H-CC, had extremely low foraminiferal content because of an influx of volcanic material. Samples 340-U1396A-13H-CC and 340-U1396C$13 \mathrm{H}-\mathrm{CC}$ can still, however, be dated to the Sphaeroidinellopsis seminulina Zone (PL3), as they contain $S$. seminulina. Species abundances in the Pleistocene generally conform to the previous sites (U1394 and U1395), with Globigerinoides ruber and Globigerinoides sacculifer being the two most dominant species. Throughout the Pliocene these abundances shift, with a distinct increase in the keeled genus Globorotalia (specifically: Globorotalia exilis, Globorotalia pertenuis, Globorotalia menardii, and Globorotalia miocenica) becoming more common.

Every planktonic foraminiferal biozone and subzone from the Quaternary to the lower Pliocene was recorded (Zones PT1b, PT1a, PL6, PL5, PL4, PL3, PL2, and PL1). Several differences exist between the two main holes, U1396A and U1396C. Hole U1396A does not appear to capture the 30,000 y long Zone PL4 (Dentoglobigerina altispira Highest Occurrence Zone [HOZ]), although it was identified in Hole U1396C. Postcruise analysis of Hole U1396A may still identify this zone, likely within Core 340-U1396A10H. Additionally, Zone PL1 (Globorotalia tumida/ Globoturborotalia nepenthes Concurrent Range Zone (CRZ) [Atlantic]) was identified at the base of Hole U1396A (Sample 340-U1396A-15H-CC) but not in Hole U1396C. Again, further analysis of Core 340- 
U1396C-15H may reveal the presence of G. nepenthes, which would indicate Zone PL1. Core catcher Sample 340-U1396C-3H-CC contains both Globorotalia tosaensis and Globorotalia flexuosa, which have conflicting and nonconcurrent ranges. The missing 21,000 y interval between when $G$. flexuosa goes extinct and G. tosaensis originates appears to have been the victim of time averaging, either through bioturbation, drilling, or some other mechanism. The primary marker between Subzone PT1a and Zone PL6 (Globigerinoides fistulosus) was not recorded at the expected depth, above the base of Globorotalia truncatulinoides. G. fistulosus was recorded in only three samples (340-U1396A-3H-CC and 340-U1396C-5H$\mathrm{CC}$ and $6 \mathrm{H}-\mathrm{CC})$. Zone PL6 was recognized, instead, on the base of $G$. truncatulinoides, the first secondary datum within Zone PL6. Many different datums were recorded: G. flexuosa (0.07-0.40 Ma), G. tosaensis (top occurrence $[\mathrm{T}]$ at $0.61 \mathrm{Ma})$, G. exilis (T $2.1 \mathrm{Ma})$, Globigerinoides extremus (T 2.1 Ma), G. miocenica (T 2.39 Ma), G. pertenius (T $2.60 \mathrm{Ma}$ ), Globorotalia multicamerata (T $2.99 \mathrm{Ma})$, S. seminulina (T $3.16 \mathrm{Ma})$, Pulleniatina primalis (T $3.65 \mathrm{Ma}$ ), Globorotalia margaritae (T $3.84 \mathrm{Ma}$ ), and $G$. nepenthes (T $4.36 \mathrm{Ma}$ ). Although several more first appearance datums (B) are calibrated through this interval as secondary markers, when compared against the datums listed above they appear to be largely unreliable as age determinations at this site and were not used.

\section{Benthic foraminifers}

A total of 41 genera and 44 species were identified at Site U1396 in the $>150 \mu \mathrm{m}$ size fraction. Benthic foraminifers examined in Holes U1396A, U1396B, and U1396C varied in abundance, diversity, and preservation (moderate). Hole U1396A has the greatest number of species (40), followed by Hole U1396B (25) and then Hole U1396C (4). Rotaliids have low diversity and are present in low abundances (1-10 specimens per sample) overall in Holes U1396A and U1396C. Cibicides and Cibicidoides are the dominant genera in Hole U1396A but are nearly absent in Holes U1396B and U1396C. Cibicides wuellerstorfi is the most abundant species in Hole U1396A. Similarly, buliminids have low diversity with low abundances (1-10 specimens per sample) overall in Holes U1396A and U1396C. However, buliminids dominate the assemblage in Samples 340-U1396A-4H-CC, 5H-CC, 8H-CC, and $9 \mathrm{H}-\mathrm{CC}$ and 340-U1396C-3H-CC, 4H-CC, and 8HCC. Miliolids are practically absent in most samples, with the exception of Pyrgo murrhina, the dominant species. Agglutinated foraminifers are represented by the genera Sigmoilopsis, Bigenerina, and Vulvulina, with Karreriella bradyi as the dominant species. Benthic foraminiferal density is generally low at Site U1396, ranging between 1 and 67 foraminifers/g of sediment.
However, Samples 340-U1396A-5H-CC and 10H-CC and 340-U1396C-4H-CC and 13H-CC have densities of 214, 111, 156, and 113 foraminifers/g of sediment, respectively.

At Site U1396, Myllostomella costai, Myllostomella huygaensis, Orthomorphina jedlitschkai, Orthomorphina perversa, Pleurostomella alternans, Proxifrons inaequalis, Siphonodosaria cooperensis, Siphonodosaria insecta, Siphonodosaria pomuligera, Siphonodosaria sargrinensis, Stilostomella fistuca, and Vulvulina pennatula are present in relative low abundances (1-10 specimens per sample) in most samples. This group has a last appearance datum (T) at $0.58 \mathrm{Ma}$ (Hayward et al., 2006). S. cooperensis has a moderate abundance (1-30 specimens per sample) in Samples 340-U1396A-4H-CC, 5H-CC, and $6 \mathrm{H}-\mathrm{CC}$. Based on the presence and persistence of the above group, a bathyal paleodepth is interpreted.

\section{Geochemistry}

Samples for headspace analyses were taken from 15 depths throughout Hole U1396A. The uppermost sample (from Section 340-U1396A-1H-3) has a methane concentration of $3.6 \mathrm{ppm}$, but all other samples have levels between 2.1 and $2.6 \mathrm{ppm}$. No higher hydrocarbons were detected.

A total of 30 samples were taken for X-ray diffraction (XRD) and carbonate analysis. No pure volcanic samples were collected from Hole U1396A. In contrast to the previous sites, high Mg-calcite was only present in one section (340-U1396A-6H-2). All other carbonaterich layers contain pure calcite and aragonite in variable proportions, with calcite generally dominant. Clay minerals are ubiquitous throughout the hole, with smectite and kaolinite present in all samples and glauconite commonly identified (e.g., Section 340-U1396A-9H-2; Fig. F4A). Halloysite may be present in some samples, but the spectra are not clear enough to be certain. The bulge beneath the main peaks in some of the volcanic-rich samples (e.g., Section 340-U1396A-12H-5; Fig. F4B) suggests that significant amounts of volcanic glass are present in some tephra layers.

$\mathrm{CaCO}_{3}$ and organic carbon abundances reflect mixtures of carbonate-rich hemipelagic sediments with carbonate-free and organic carbon-free volcanogenic material delivered by ash fallout. The highest $\mathrm{CaCO}_{3}$ concentration was only $72 \mathrm{wt} \%$, with most samples having much lower levels, suggesting that volcanic material is dispersed throughout the core even where it is not visible to the naked eye (Fig. F5; Table T2).

Samples for pore water extraction were taken from every core from Hole U1396C (Fig. F6; Table T3). Alkalinity values are generally low $(<1.5 \mathrm{mM})$ throughout the hole (Fig. F6A). pH values are generally lower 
(7.6-7.1) than those at Sites U1394 and U1395, but no consistent pattern is observable in the data. Ammonia concentrations are much lower than those at the previous two sites (Fig. F6B). These differences may be related to the fact that Site U1396 is located at shallow depths on a basement high, where strong bottom currents have been observed on previous research cruises to the area. This effect tends to winnow out the finer grained, more reactive organic matter and leads to less intense organic carbon-driven diagenesis. Calcium concentrations are consistently higher than bottom water values in samples from throughout the hole (Fig. F6C), and magnesium concentrations are consistently lower than seawater concentrations (Fig. F6D). These features are commonly seen in deep sediment pore water as a result of alteration of basaltic glass and suggest that many of the tephra layers observed in the core may have a basaltic composition. This hypothesis is supported by the potassium concentrations which are also lower than seawater (Fig. F6E). Overall, $\Sigma$ S concentrations are slightly depleted relative to seawater sulfate values but do not show a particularly distinct trend with depth. Chloride concentrations fluctuate within the normal range (550-570 $\mathrm{mM}$ ) expected for pore water obtained from squeezing carbonate-rich sediment (Table T3).

Three samples were taken for shore-based microbiological analyses after the piston core had been preloaded with a microsphere bag to assess potential surface contamination. However, the bag failed to burst at the bottom of the hole. A total of $20 \mathrm{~g}$ of sediment was taken for shore-based microbiological activity measurements and stored at $0^{\circ} \mathrm{C}$. A total of $4 \mathrm{~g}$ of sediment was taken for shore-based RNA analysis and stored at $-80^{\circ} \mathrm{C}$.

\section{Physical properties}

We collected physical properties data between 0 and 140 mbsf at Holes U1396A and U1396C. We also collected physical properties data between $\sim 5$ and 15 mbsf at Hole U1396B to fill a gap in the data from Hole U1396A. Good correlation exists between holes. Magnetic susceptibility provides the most valuable tool for differentiating stratigraphic changes at this site. $P$-wave and density measurements are consistent but show little variability with depth. Porosity measurements in sandy sediment are anomalously high, possibly an artifact of the core recovery process. All shear strength measurements increase monotonically with depth, with a few anomalous values. Temperature increases linearly with depth, with a temperature gradient of $69.3^{\circ} \pm 1.5^{\circ} \mathrm{C} / \mathrm{km}$. There is no evidence for fluid advection disturbing the temperature measurements.

\section{Stratigraphic correlation between Holes U1396A and U1396C}

We used magnetic susceptibility to correlate depths between Holes U1396A, U1396B, and U1396C (Figs. F7, F8). Hole U1396C is the reference hole for these correlations because it has the longest continuous record. Core 340-U1396A-2H shattered during coring, and although much of the sediment from the core was recovered, placed into core barrels on deck, and scanned on the Whole-Round Multisensor Logger (WRMSL), there is a chance that a significant amount of the material was disturbed during this process. We therefore removed all WRMSL data for Core 340-U1396A-2H from the correlation analysis. Core $340-\mathrm{U} 1396 \mathrm{~B}-2 \mathrm{H}$ covers most of the depth range missing from Hole U1396A for correlation. By correlating both Holes U1396A and U1396B to Hole U1396C, we were able to make a nearly complete correlation at Site U1396. Core 340-U1396B-1H had all depth values set to 5 mbsf when we downloaded the data (this has since been changed); therefore, we applied a linear interpolation for Core 340-U1396B$1 \mathrm{H}$ to correlate this upper core with Hole U1396C. Holes U1396A and U1396B correlate well with Hole U1396C, with correlation coefficients of 0.75 and 0.79 , respectively (Figs. F7, F8). Depth shifts for all correlation corrections for Holes U1396A and U1396B never exceeded $3 \mathrm{~m}$ and rarely exceeded $1 \mathrm{~m}$. In the uppermost $7 \mathrm{~m}$, we see clear correlation of turbidite units between the two holes. All correlation pick depth shifts are shown in Tables T4 and T5.

\section{Gamma ray attenuation density, magnetic susceptibility, and $P$-wave velocity}

Magnetic susceptibility identifies volcaniclastic layers embedded in the hemipelagic background. Natural gamma radiation (NGR) shows low-amplitude and low-frequency variations with depth on a wavelength of one to two core lengths. NGR values are generally anticorrelated with magnetic susceptibility anomalies. Gamma ray attenuation (GRA) density does not have any systematic trend or correlation with volcaniclastic layers.

\section{Thermal conductivity}

Thermal conductivity was measured on 50 sections. The mean value was $1.041 \mathrm{~W} /(\mathrm{m} \cdot \mathrm{K})$ with a standard deviation of $0.079 \mathrm{~W} /(\mathrm{m} \cdot \mathrm{K})$ and a standard error of the mean of $0.010 \mathrm{~W} /(\mathrm{m} \cdot \mathrm{K})$.

\section{Shear strength}

Handheld penetrometer measurements of undrained shear strength $\left(S_{\mathrm{u}}\right)$ in Holes U1396A and U1396C are consistent and show a general trend that increases 
downhole. No measurements were performed in Hole U1396B. $S_{\mathrm{u}}$ measurements conducted with the automated vane shear (AVS) also show a trend of increasing shear strength with depth in both holes. Within this trend, a few low values are observed at 85,115 , and 130 mbsf.

\section{P-wave velocities}

Discrete measurements of $P$-wave velocity measured on the $x$-axis (PW-X) identify the volcaniclastic layers as having high velocity (1650-1800 m/s) compared to the hemipelagic sediment (1550-1650 m/s). Such measurements were only possible where tephra layers were thicker than the transducer's caliper separation $(3 \mathrm{~cm})$. $\mathrm{PW}-\mathrm{X}$ measurements generally match $P$-wave logger (PWL) measurements on the WRMSL.

\section{Moisture and density}

We collected 35 moisture and density (MAD) samples (32 from Hole U1396A and 3 from Hole U1396C; Figs. F9, F10). Porosity ranges from $\sim 54 \%$ to $70 \%$, with one volcanic sand sample having a porosity of $50 \%$. Porosity shows no clear trend with depth. We caution that our calculated porosity values in high-permeability sediments such as volcanic turbidites may be too low because many of the samples drained water when we removed them from the working half of the split core. When we baked these samples, less water was present for removal, resulting in porosities that will be systematically lower than true values. Normally compacted sands do not typically have porosities $>50 \%$. The deepest sediments at Site U1396 are $\sim 4.5 \mathrm{Ma}$ in age and sedimentation rates are low (see "Paleomagnetism"), implying that no significant overpressure or anomalously high porosities should exist at this site. We therefore suggest that the anomalously high porosities we observe in sandy sediment at Site U1396 may result from significant reworking of the sediment during core recovery and splitting. Bulk density ranges from 1.45 to $2.00 \mathrm{~g} / \mathrm{cm}^{3}$. Grain density ranges between 2.65 and $2.8 \mathrm{~g} / \mathrm{cm}^{3}$.

\section{Downhole temperature}

Temperature was measured with the APCT-3 at the bottom of Cores 340-U1396A-3H, $4 \mathrm{H}, 5 \mathrm{H}$, and $6 \mathrm{H}$ (24.6, 34.1, 43.6, and $53.1 \mathrm{mbsf}$, respectively) and Cores 340-U1396C-6H and 11H (55.9 and 103.4 mbsf, respectively). Downhole temperature was monitored for $320,316,346,654,943$, and 2281 s, respectively. Temperature was calculated from these time series of temperature measurements using TP-Fit (see APCT-3 user manual on the Cumulus/Techdoc database at iodp.tamu.edu/tasapps/). We assume a thermal con- ductivity $(k)$ of $1.0 \mathrm{~W} /(\mathrm{m} \cdot \mathrm{K})$ and $\rho \mathrm{C}=3.7 \times 10^{6} \mathrm{~J} / \mathrm{m}^{3} \mathrm{~K}$. To calculate uncertainty, we assume $k$ ranges from 0.9 to $1.1 \mathrm{~W} /(\mathrm{m} \cdot \mathrm{K})$ and $\rho \mathrm{C}$ is between $3.2 \times 10^{6}$ and $4.0 \times 10^{6} \mathrm{~J} / \mathrm{m}^{3} \mathrm{~K}$. At the base of Cores $340-\mathrm{U} 1396 \mathrm{~A}$ $3 \mathrm{H}, 4 \mathrm{H}, 5 \mathrm{H}$, and $6 \mathrm{H}$ we obtained temperatures of $7.62^{\circ} \pm 0.02^{\circ} \mathrm{C}, 8.33^{\circ} \pm 0.02^{\circ} \mathrm{C}, 8.79^{\circ} \pm 0.02^{\circ} \mathrm{C}$, and $9.64^{\circ} \pm 0.02^{\circ} \mathrm{C}$, respectively. At the base of Cores 340$\mathrm{U} 1396 \mathrm{C}-6 \mathrm{H}$ and $11 \mathrm{H}$ we obtained temperatures of $9.87^{\circ} \pm 0.02^{\circ} \mathrm{C}$ and $13.07^{\circ} \pm 0.01^{\circ} \mathrm{C}$, respectively. We have no reliable measure of the temperature of ocean water at the seafloor. Computed uncertainties are similar to the error on the best-fit solution and the probe's measurement accuracy.

A best-fit linear relationship between depth and our six temperature measurements gives a temperature gradient of $69.3^{\circ} \pm 1.5^{\circ} \mathrm{C} / \mathrm{km}$ (Fig. F10). Using measured thermal conductivity, the implied heat flow, if conductive, is $72 \pm 2 \mathrm{~mW} / \mathrm{m}^{2}$. The near-surface heat flow at this site is reduced by $2 \%$ owing to the bathymetry, and sedimentation has a negligible effect on heat flow (Manga et al., 2012). There is no statistically significant deviation of the measurements from a straight line, and hence there is no signature of fluid flow in the temperature measurements (Manga et al., 2012).

\section{Paleomagnetism}

Cores 340-U1396A-1H through 12H, 340-U1396B$2 \mathrm{H}$, and $340-\mathrm{U} 1396 \mathrm{C}-1 \mathrm{H}$ through $15 \mathrm{H}$ were recovered using nonmagnetic core barrels with the APC. All other APC cores were recovered using standard steel barrels. The FlexIt orientation tool was used on all APC cores recovered with nonmagnetic barrels; thus, declination for 0-107.4 mbsf in Hole U1396A, 5-15 mbsf in Hole U1396B, and 0-139.5 mbsf in Hole U1396C can be corrected to true north. Where FlexIt tool data were not available in Hole U1396A, declination was guided by the discrete inclination data (see "Paleomagnetism" in the "Methods" chapter [Expedition 340 Scientists, 2013]). Expected inclination for the site is $30.7^{\circ}$ during normal polarity and $-30.7^{\circ}$ during reversed polarity, assuming a geocentric axial dipole (GAD). The archive halves of cores from Holes U1396A, U1396B, and U1396C were measured on the three-axis superconducting rock magnetometer (SRM) at $2.5 \mathrm{~cm}$ intervals (Table T6). Natural remanent magnetization (NRM) was measured before $\left(\mathrm{NRM}_{0}\right)$ and after stepwise alternating field demagnetization at $10 \mathrm{mT}\left(\mathrm{NRM}_{10}\right)$ and $20 \mathrm{mT}$ $\left(\mathrm{NRM}_{20}\right)$. Core $340-\mathrm{U} 1396 \mathrm{~B}-2 \mathrm{H}$ was substituted into the Hole U1396A record using magnetic susceptibility correlations (see "Physical properties") because Core 340-U1396A-2H was highly disturbed after the core liner shattered. Eighteen discrete samples were 
collected from the center of the working half of the core to compare to the SRM data (see "Paleomagnetism" in the "Methods" chapter [Expedition 340 Scientists, 2013]).

Cores are dominated by hemipelagic sediment but also contain many centimeter-scale fine-grained tephra layers from numerous eruptions of the Lesser Antillies volcanic arc (see "Lithostratigraphy").

\section{Results}

$\mathrm{NRM}_{0}$ (red) and $\mathrm{NRM}_{20}$ (blue) intensities are shown for Holes U1396A and U1396B in Figure F11 and Hole U1396C in Figure F12. $\mathrm{NRM}_{0}$ intensity is relatively high at $\sim 0.5 \mathrm{~m} / \mathrm{A}$. Discrete tephra layers produce a strong magnetic susceptibility response (see "Physical properties"), and similarly high values of $\mathrm{NRM}_{0}$ related to the concentration of ferrimagnetic minerals.

A strong magnetic overprint characterized by a steep SRM inclination and divergence of SRM and discrete inclination data is restricted to Cores 340-U1396A$13 \mathrm{H}$ through $15 \mathrm{H}$. These cores were recovered using steel barrels. Agreement of SRM and discrete declination values from these cores suggests the radial overprint is less affected than the vertical overprint and declination can still be used for interpretation of polarity.

\section{Magnetostratigraphy}

Sedimentation rates for the site were predicted to be $\sim 2-3 \mathrm{~cm} / \mathrm{k} . \mathrm{y}$. from analysis of a $6 \mathrm{~m}$ gravity core (Le Friant et al., 2008). Extrapolation of these rates over the full $140 \mathrm{~m}$ record of Hole U1396C suggests the site could contain a 4-5 m.y. record of sedimentation. Inclination and declination for Holes U1396A, U1396B, and U1396C are shown in Figures F11 and F12. The Hole U1396A/U1396B record contains fifteen $180^{\circ}$ shifts in declination in which declination stabilized before again reversing. The Hole U1396C record contains sixteen such reversal horizons. Changes in inclination are coeval with declination changes moving between positive and negative GAD values during these events. However, as only a $60^{\circ}$ transition marks an inclination reversal, some of the shorter features that are clear in $180^{\circ}$ declination shifts are not as obvious in inclination.

Using magnetic susceptibility to correlate between Holes U1396A, U1396B, and U1396C (see "Physical properties"), Holes U1396A and U1396B was transferred onto the more complete and longer depth scale of Hole U1396C to provide an aggregated reversal record (Fig. F13). This transfer also allowed more accurate splicing of the Hole U1396B record into the Hole U1396A record. This record is now referred to as Hole U1396A/B. On a common depth scale the two declination records agree very well and suggest that the geomagnetic field was accurately recorded in the sediment at Site U1396.

Using the geomagnetic polarity timescale (GPTS) of Cande and Kent (1995), eight periods of normal polarity and nine periods of reversed polarity were determined in Hole U1396A/B and nine normal polarity and nine reversed polarity episodes in Hole U1396C. The earliest polarity reversal in Hole U1396A is the beginning of Chron C3n.1n (4.29 Ma) at 129.4 mbsf, giving Hole U1396A a basal age of 4.29-4.48 Ma. The longer Hole U1396C record contains the end of Chron C3n.2n (4.48 Ma), giving the hole a basal age of 4.48-4.62 Ma. These ages are in excellent agreement with nannofossil and foraminiferal ages, which put the base of both holes within the early Pliocene (Fig. F14; see "Paleontology and biostratigraphy").

Using the depths of the dated reversals, an age-depth relationship can be created and sedimentation rates calculated for the longer record from Hole U1396C (Fig. F14). A linear sedimentation rate calculated from the deepest reversal gives the core an average sedimentation rate of $3.1 \mathrm{~cm} / \mathrm{k} . \mathrm{y}$. However, this gradient steepens with depth in all three stratigraphic proxies. Pliocene sedimentation rates are double $(4 \mathrm{~cm} / \mathrm{k} . \mathrm{y}$.$) the Pleistocene rates (1.7 \mathrm{~cm} / \mathrm{k} . \mathrm{y}$.$) , and$ rates within the earliest $1 \mathrm{~m}$.y. of the record from the base of the core to the beginning of the Gauss Chron (3.58 Ma) are even higher $\sim 5.3 \mathrm{~cm} / \mathrm{k} . \mathrm{y}$.

\section{References}

Cande, S.C., and Kent, D.V., 1995. Revised calibration of the geomagnetic polarity timescale for the Late Cretaceous and Cenozoic. J. Geophys. Res., [Solid Earth], 100(B4):6093-6095. doi:10.1029/94JB03098

Cassidy, M., Trofimovs, J., Palmer, M.R., Talling, P.J., Watt, S.F.L., Moreton, S.G., and Taylor, R.N, submitted. Timing and emplacement dynamics of newly recognized mass flow deposits at $~ 8-12 \mathrm{ka}$ offshore Soufrière Hills Volcano, Montserrat: how submarine stratigraphy can complement subaerial eruption histories. J. Volcanol. Geotherm. Res.

Expedition 340 Scientists, 2013. Methods. In Le Friant, A., Ishizuka, O., Stroncik, N.A., and the Expedition 340 Scientists, Proc. IODP, 340: Tokyo (Integrated Ocean Drilling Program Management International, Inc.). doi:10.2204/iodp.proc.340.102.2013

Gartner, S., 1977. Calcareous nannofossil biostratigraphy and revised zonation of the Pleistocene. Mar. Micropaleontol., 2:1-25. doi:10.1016/0377-8398(77)90002-0

Harford, C.L., Pringle, M.S., Sparks, R.S.J., and Young, S.R., 2002. The volcanic evolution of Montserrat using ${ }^{40} \mathrm{Ar} /$ ${ }^{39}$ Ar geochronology. Mem.-Geol. Soc. London, 21:93113. doi:10.1144/GSL.MEM.2002.021.01.05 
Hayward, B.W., Kawagata, S., Grenfell, H.R., Droxler, A.W., and Shearer, M., 2006. Mid-Pleistocene extinction of bathyal benthic foraminifera in the Caribbean Sea. Micropaleontology, 52(3):245-265. doi:10.2113/gsmicropal.52.3.245

Kameo, K., and Bralower, T.J., 2000. Neogene calcareous nannofossil biostratigraphy of Sites 998, 999, and 1000, Caribbean Sea. In Leckie, R.M., Sigurdsson, H., Acton, G.D., and Draper, G. (Eds.), Proc. ODP, Sci. Results, 165: College Station, TX (Ocean Drilling Program), 3-17. doi:10.2973/odp.proc.sr.165.012.2000

Le Friant, A., Lock, E.J., Hart, M.B., Boudon, G., Sparks, R.S.J., Leng, M.J., Smart, C.W., Komorowski, J.C., Deplus, C., and Fisher, J.K., 2008. Late Pleistocene tephrochronology of marine sediments adjacent to Montserrat, Lesser Antilles volcanic arc. J. Geol. Soc. (London, U. K.), 165(1):279-289. doi:10.1144/001676492007-019
Manga, M., Hornbach, M.J., Le Friant, A., Ishizuka, O., Stroncik, N., Adachi, T., Aljahdali, M., Boudon, G., Breitkreuz, C., Fraass, A., Fujinawa, A., Hatfield, R., Jutzeler, M., Kataoka, K., Lafuerza, S., Maeno, F., Martinez-Colon, M., McCanta, M., Morgan, S., Palmer, M.R., Saito, T., Slagle, A., Stinton, A.J., Subramanyam, K.S.V., Tamura, Y., Talling, P.J., Villemant, B., Wall-Palmer, D., and Wang, F., 2012. Heat flow in the Lesser Antilles island arc and adjacent backarc Grenada Basin. Geochem., Geophys., Geosyst., 13:Q08007. doi:10.1029/2012GC004260

Okada, H., and Bukry, D., 1980. Supplementary modification and introduction of code numbers to the low-latitude coccolith biostratigraphic zonation (Bukry, 1973; 1975). Mar. Micropaleontol., 5:321-325. doi:10.1016/ 0377-8398(80)90016-X

Publication: 17 August 2013 MS 340-106 
Figure F1. Site U1396 maps. A. Shaded image of topography-bathymetry, chaotic deposits (interpreted as debris avalanche deposits), and drill sites. (Continued on next page.)

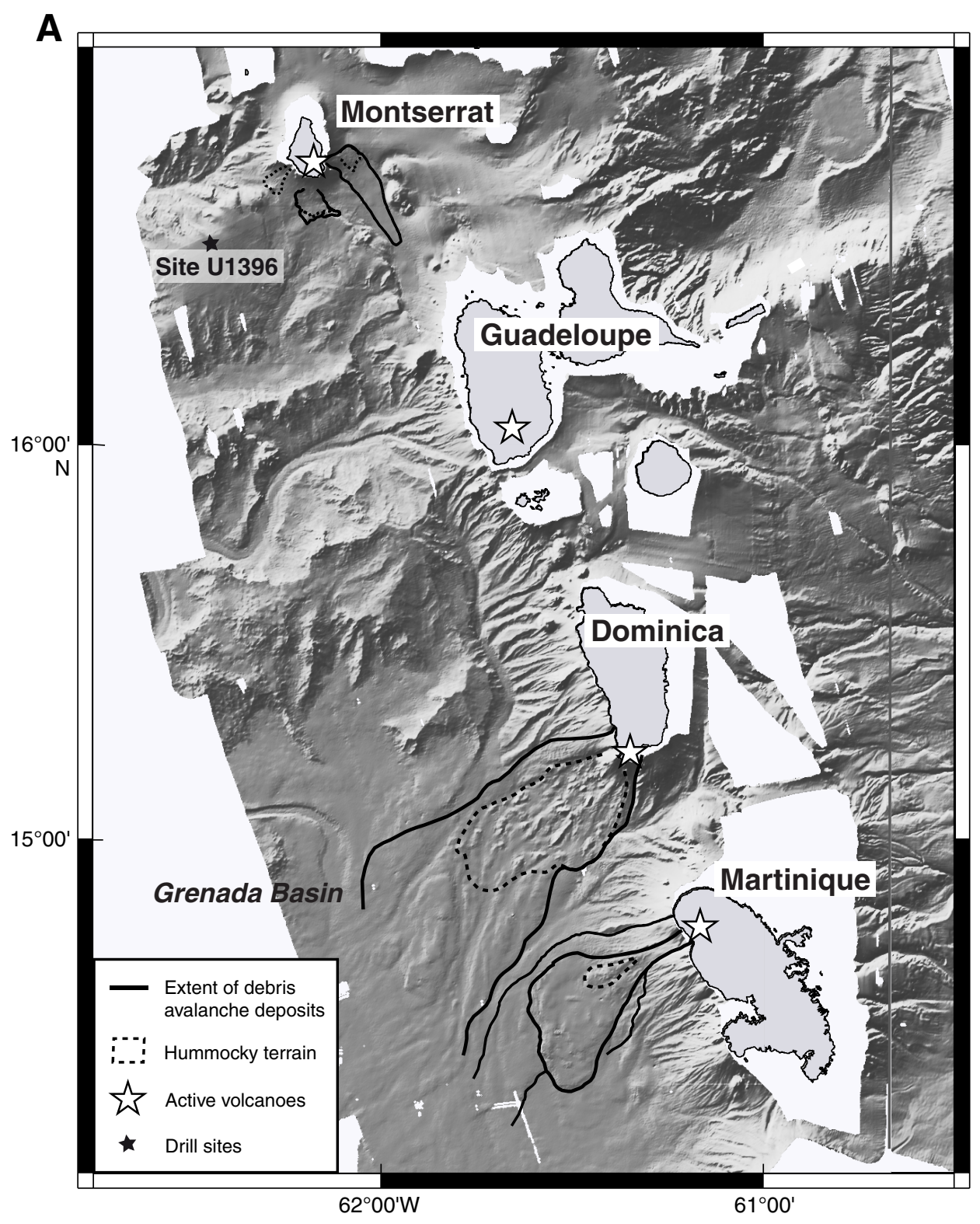


Figure F1 (continued). B. Location of seismic reflection lines, Site U1396. CDP = common depth point.

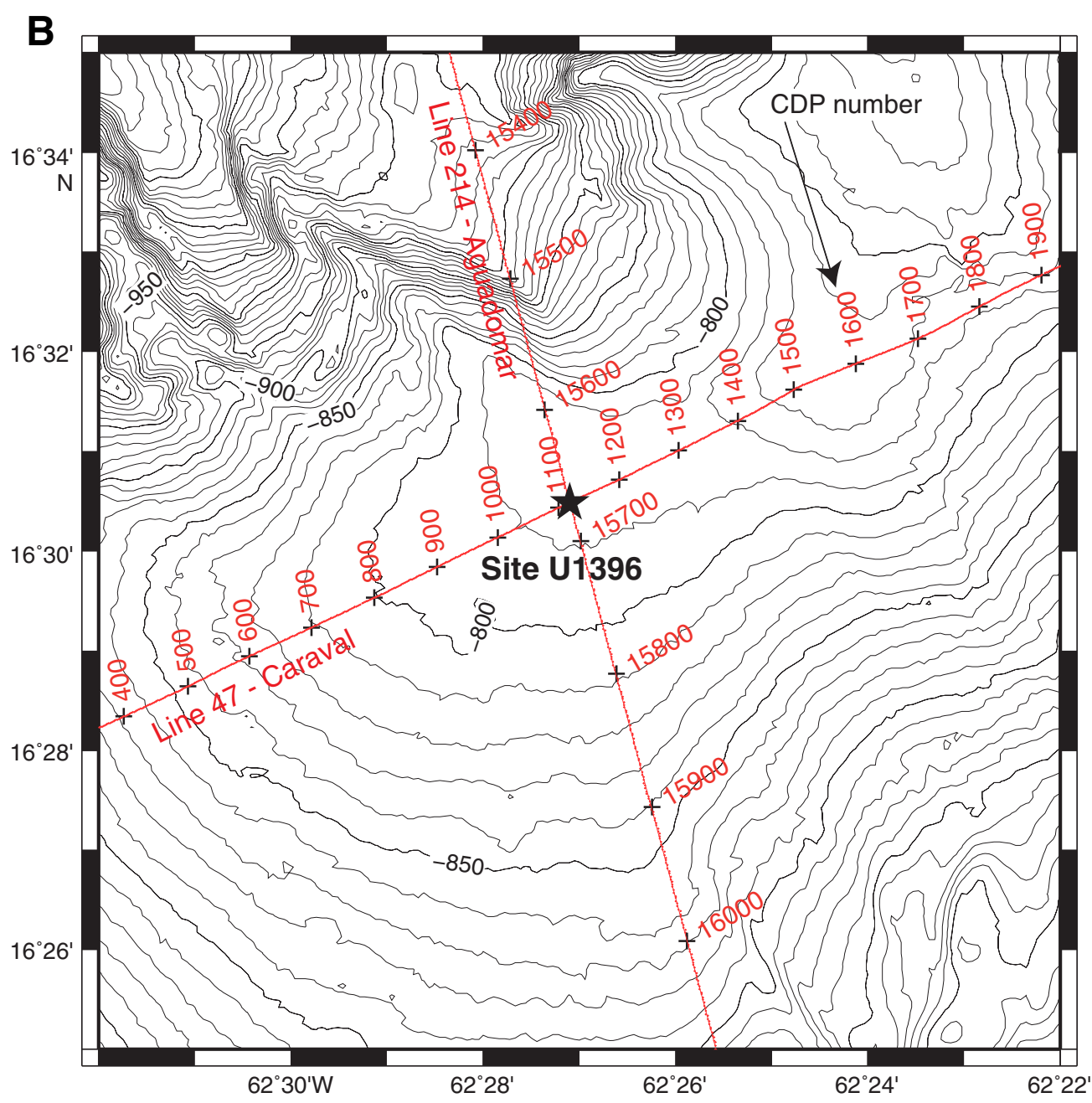


Figure F2. Distinct salmon pink pumice-rich deposit found in Holes U1396A and U1396C at 122-125 mbsf. Top of the section is at the left. Note the distinct normally graded units topped with a massive unsorted unit.

A

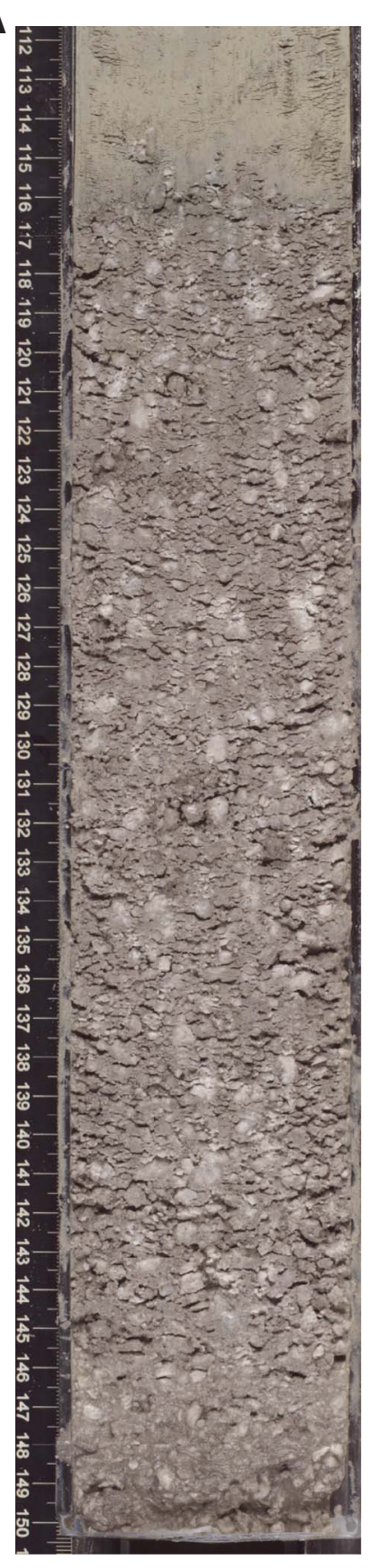

B

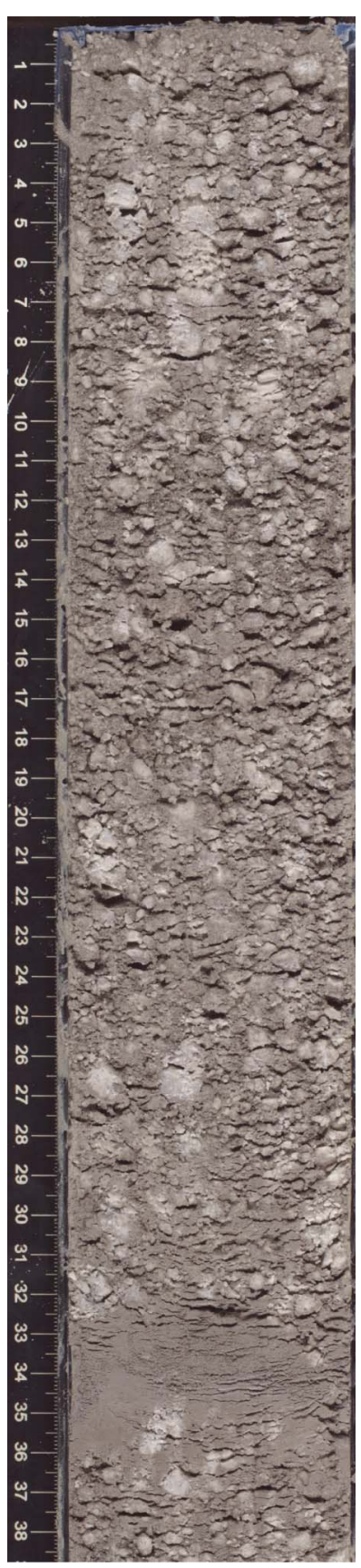

C

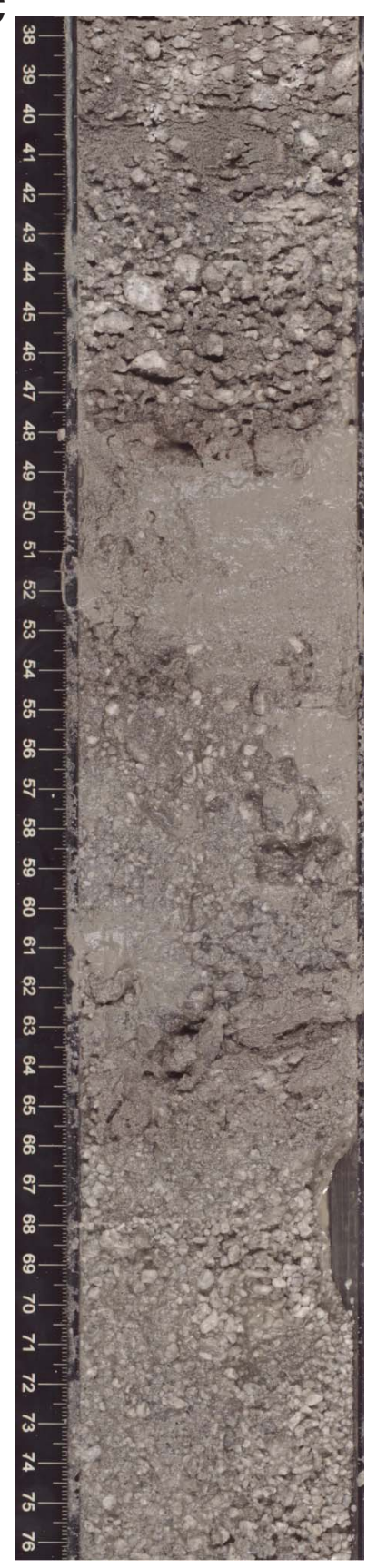

D

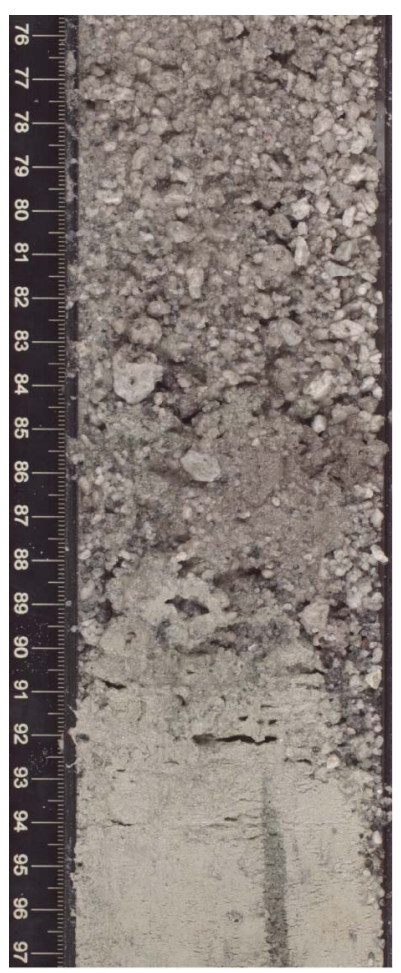


Figure F3. Integrated nannofossil and planktonic foraminiferal biozonation, Site U1396.

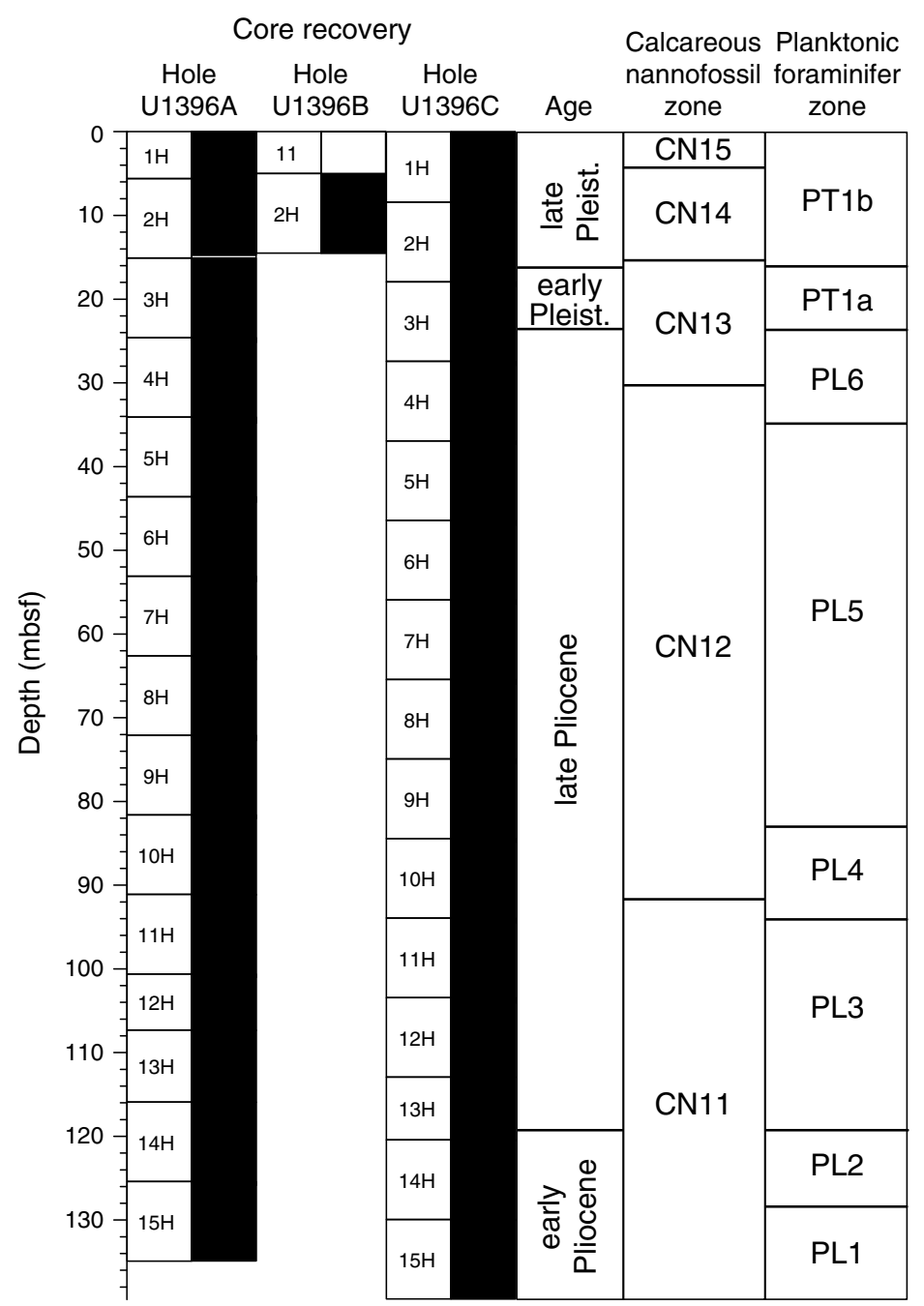



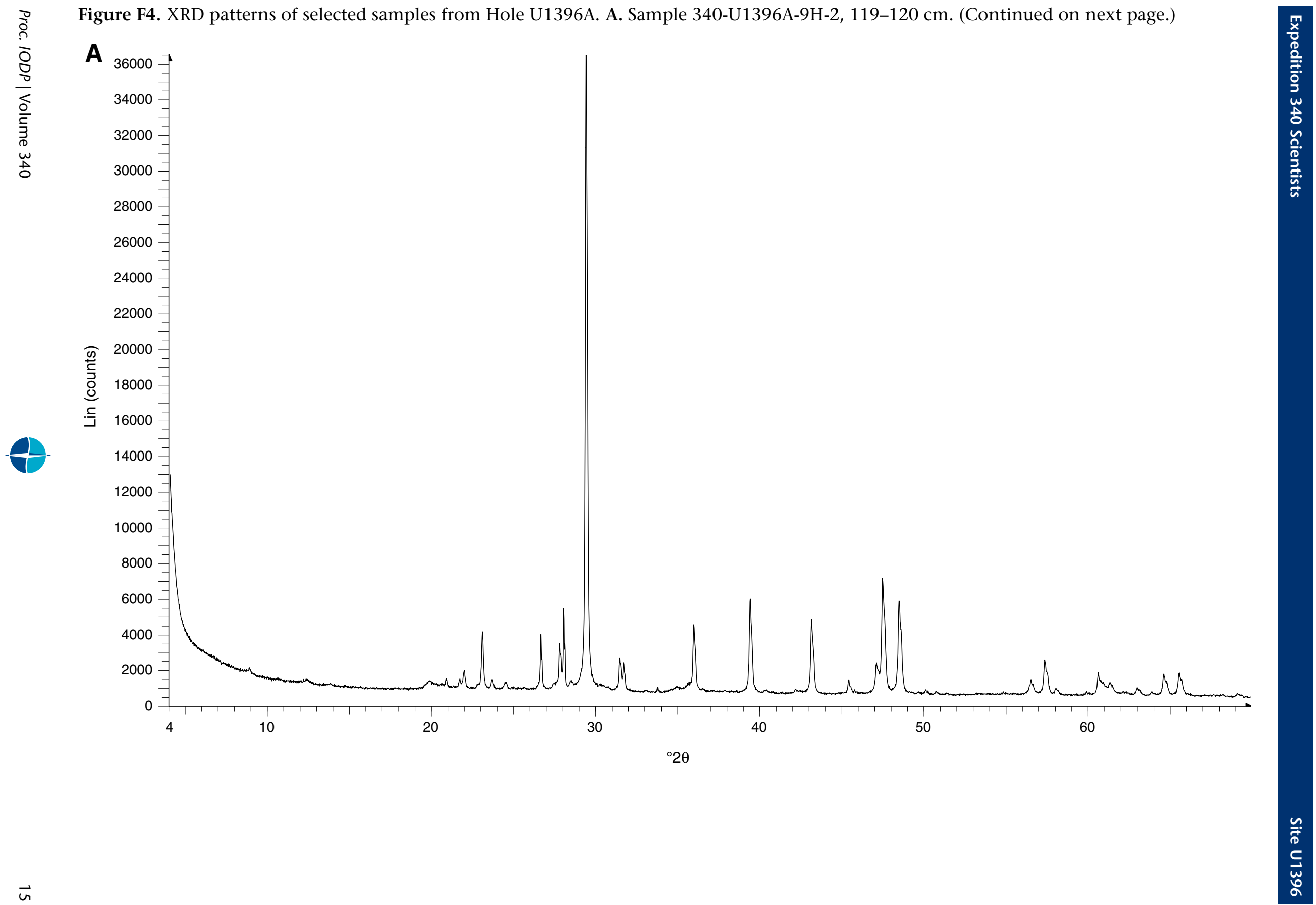


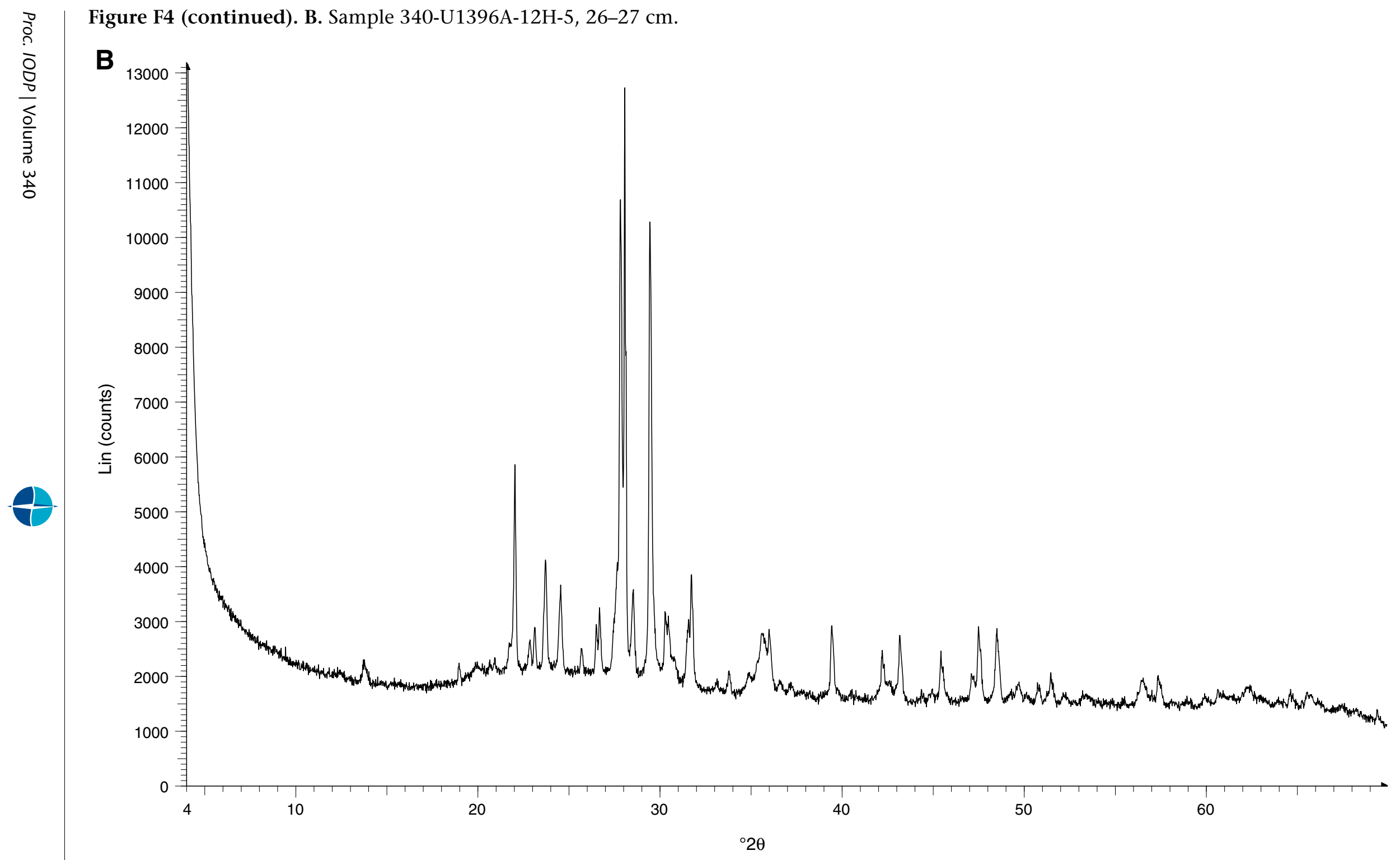


Figure F5. Solid-phase geochemical depth profiles, Site U1396. A. CaCO . B. Organic carbon.

A

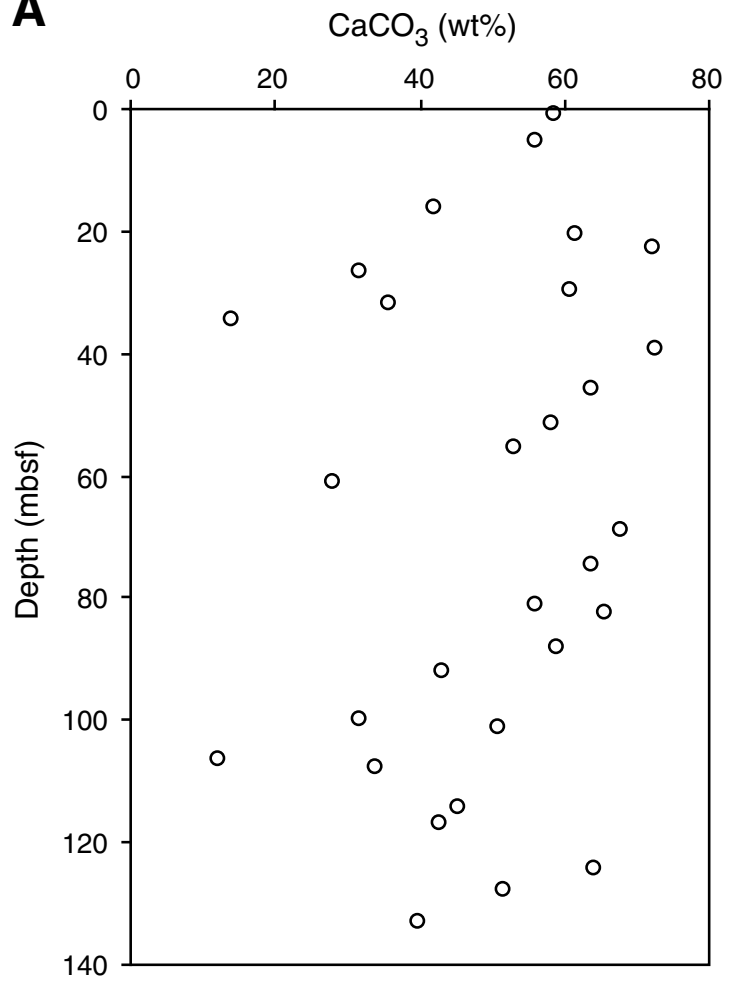

B

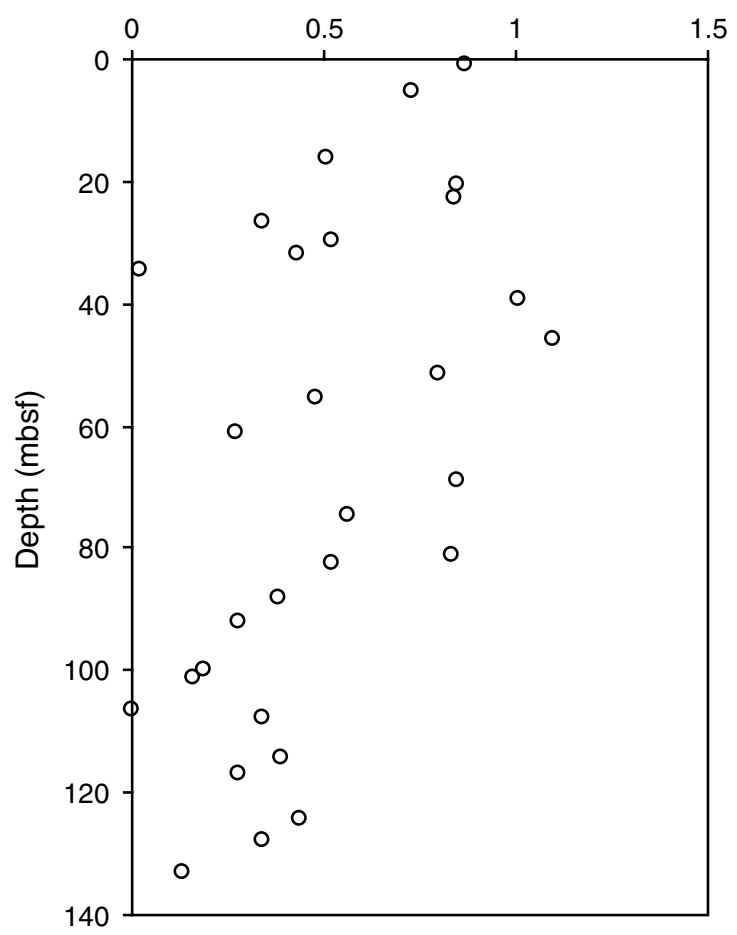




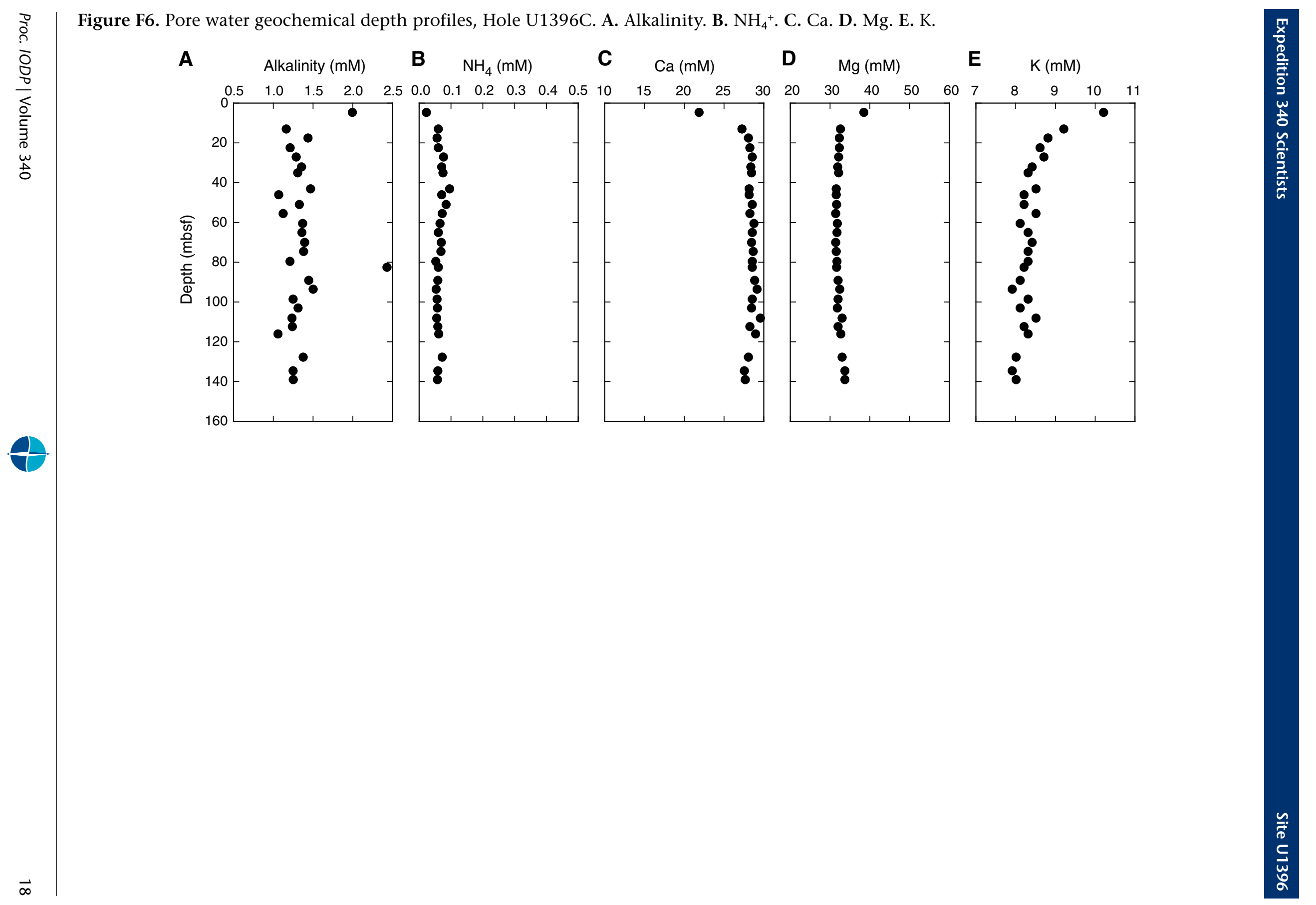


Figure F7. Magnetic susceptibility correlation of upper cores (0-50 mbsf), Holes U1396A (red) and U1396B (blue) to Hole U1396C (black). Magnetic susceptibility was measured on the Whole-Round Multisensor Logger (WRMSL). Negative values in the last column indicate a downhole shift.

Hole U1396C magnetic susceptibility $\left(10^{-5} \mathrm{SI}\right)$

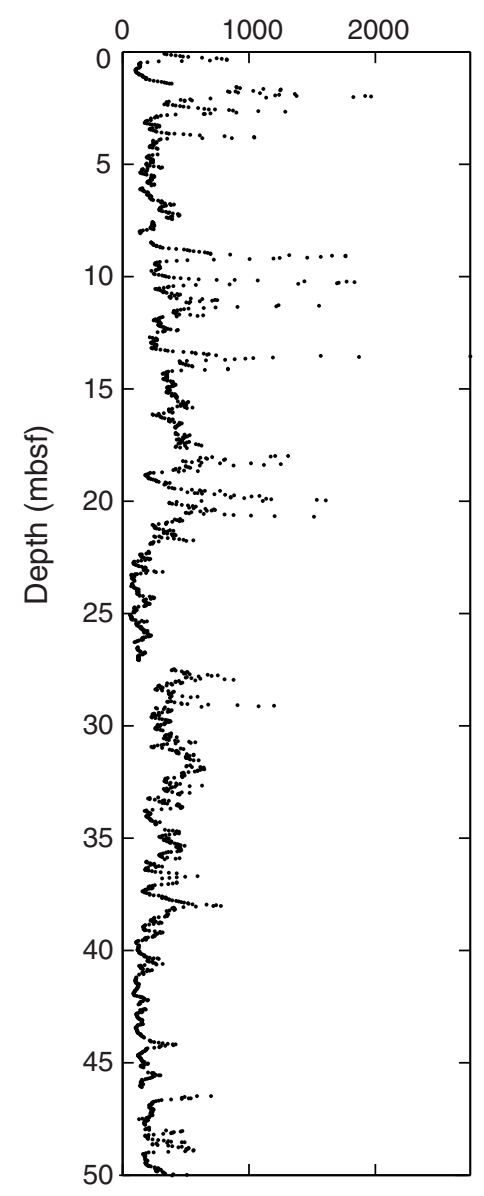

Hole U1396A

magnetic susceptibility $\left(10^{-5} \mathrm{SI}\right)$

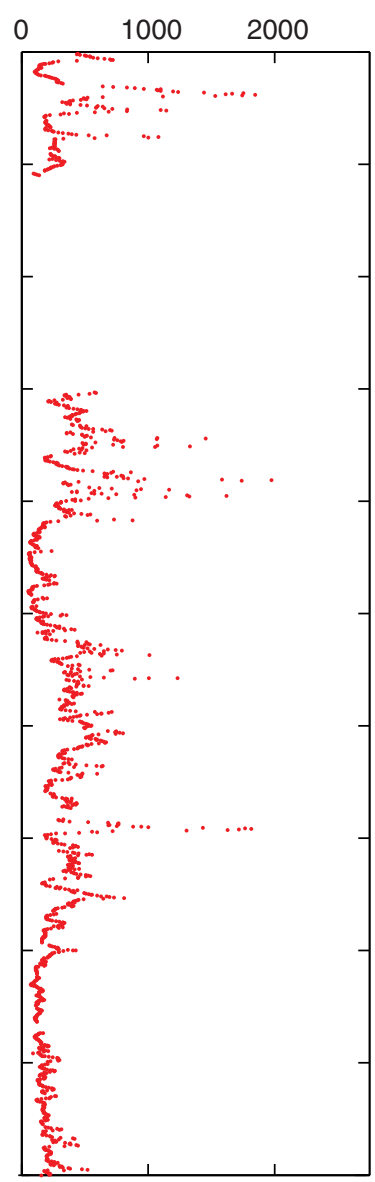

Hole U1396B $\left(10^{-5} \mathrm{SI}\right)$

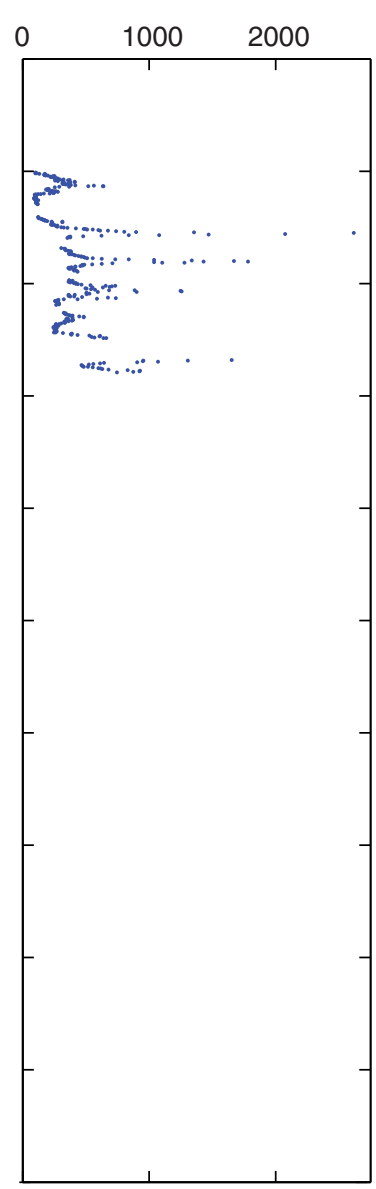

Correlated magnetic susceptibility $\left(10^{-5} \mathrm{SI}\right)$

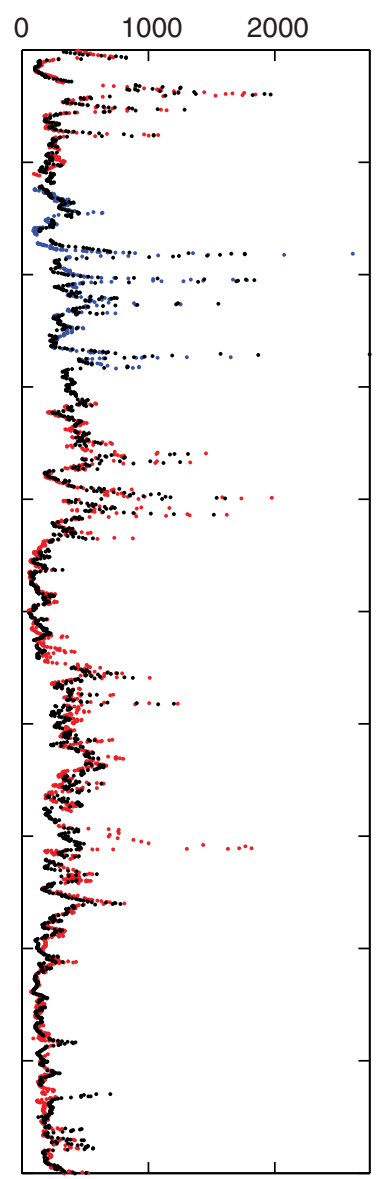

Holes U1396B and U1396A shift in depth

(m)

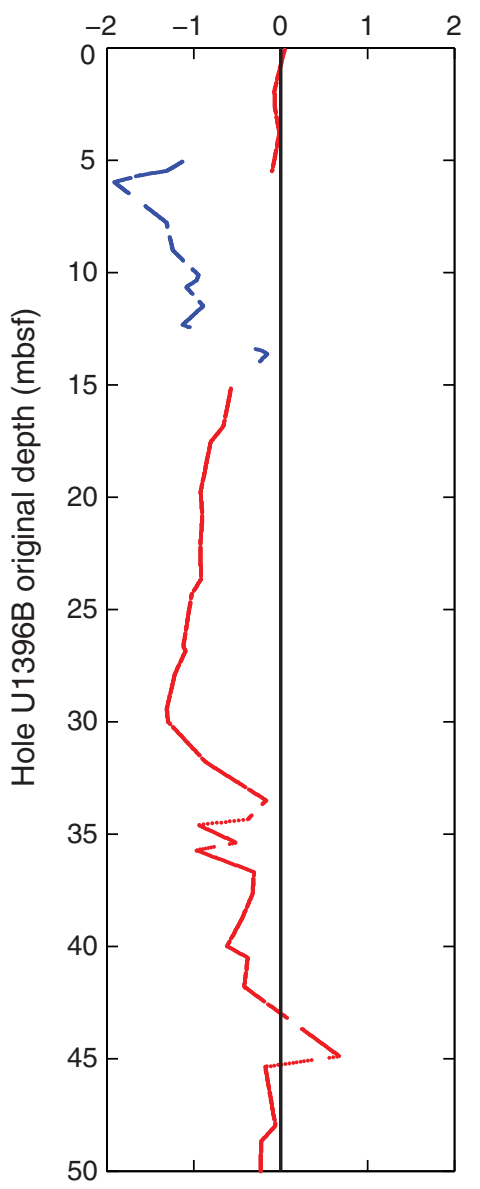


Figure F8. Magnetic susceptibility correlation of lower cores (50-140 mbsf), Hole U1396A (red) to Hole U1396C (black). Magnetic susceptibility was measured on the Whole-Round Multisensor Logger (WRMSL). Negative values in the last column indicate a downhole shift.

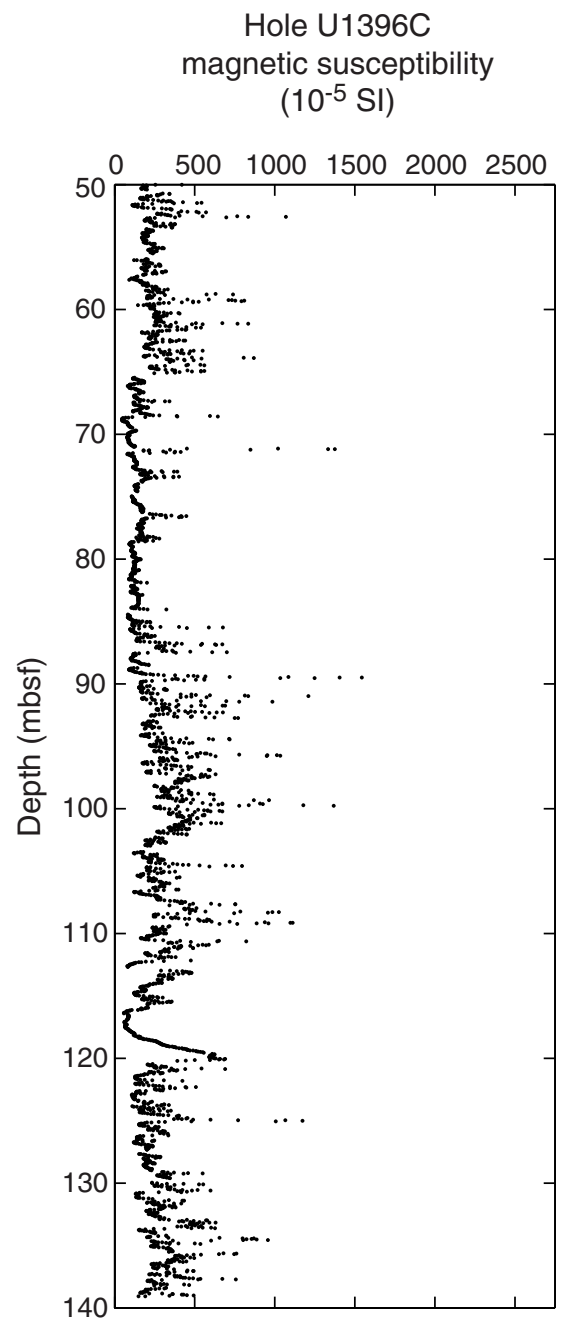

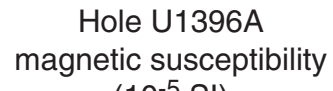

$\left(10^{-5} \mathrm{SI}\right)$

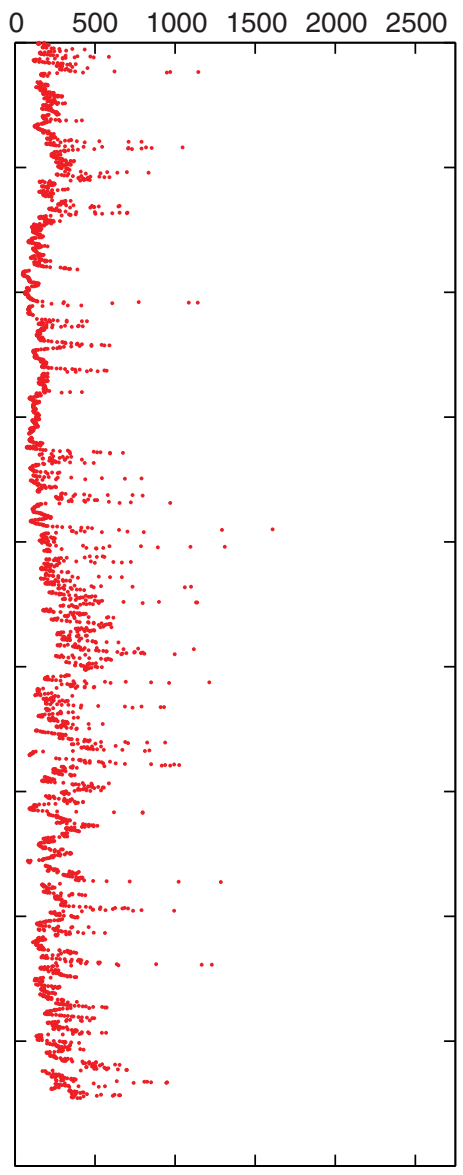

Correlated magnetic susceptibility Hole U1396A to Hole U1396C

$$
\left(10^{-5} \mathrm{SI}\right)
$$

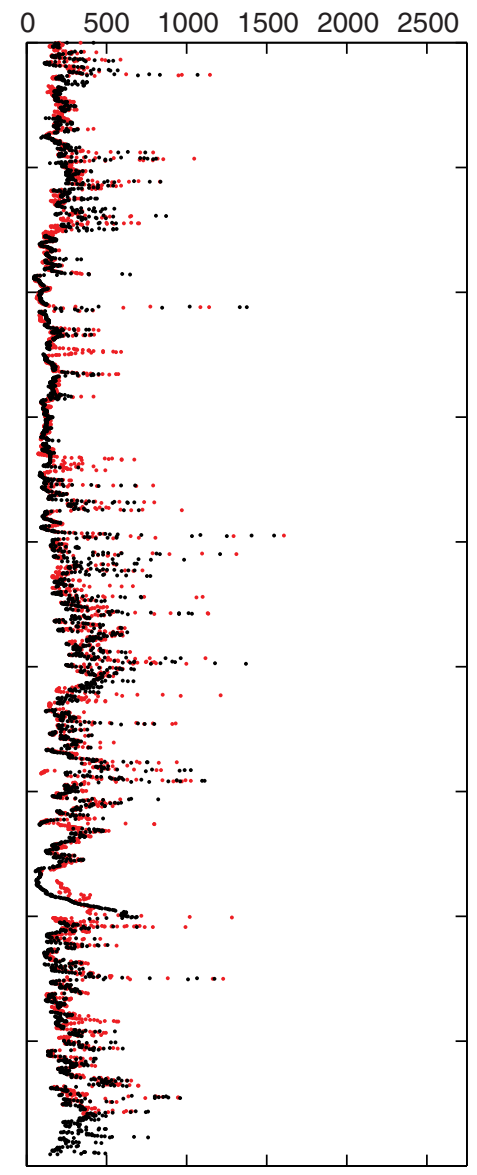

Hole U1396A shift in depth

(m)

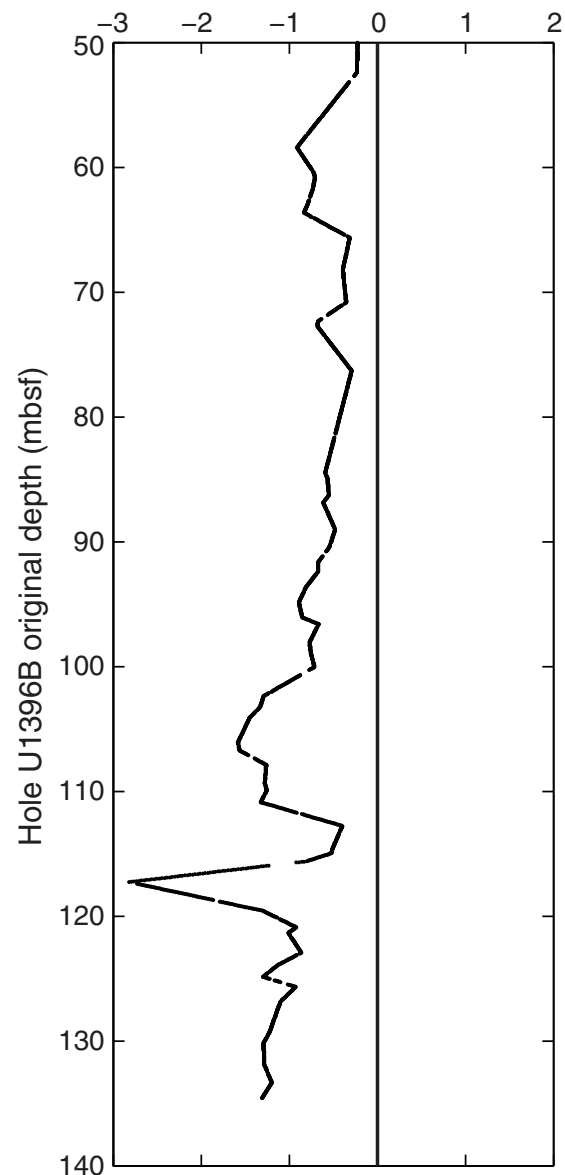


Figure F9. Physical properties, Holes U1396A (red), U1396B (green), and U1396C (blue). Whole-core data was excluded at both extremities of each core section to avoid core liner disturbances. Whole-Round Multisensor Logger (WRMSL) $P$-wave velocities were truncated when below $1500 \mathrm{~m} / \mathrm{s}$, corresponding to velocity in water. Discrete point measurements are shown with larger symbols. Vertical dashed line in the shear strength plot shows the maximum value that can be measured with the handheld penetrometer $(220 \mathrm{kPa})$. AVS = automated vane shear.
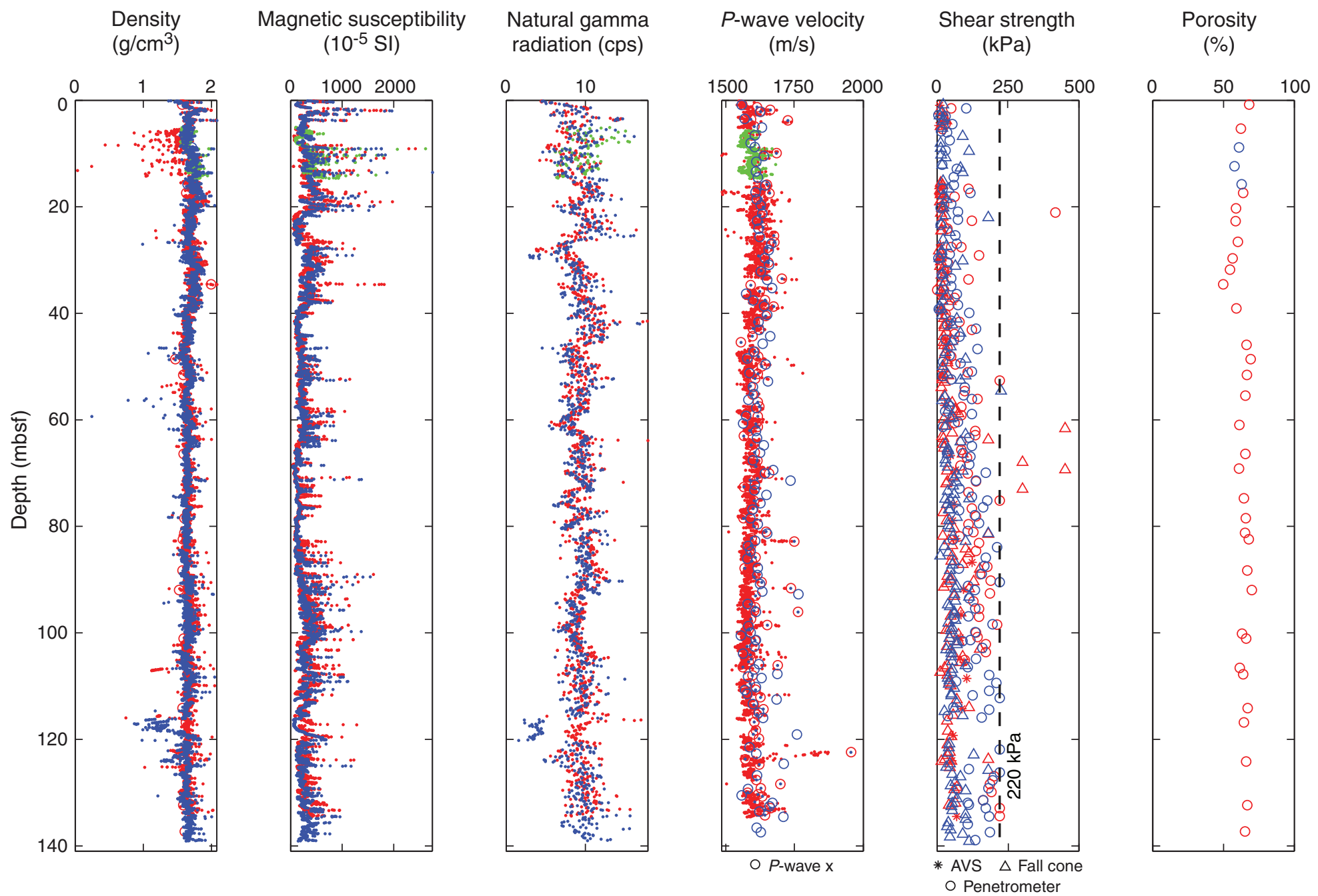

Thermal conductivity $(\mathrm{W} /[\mathrm{m} \cdot \mathrm{K}])$

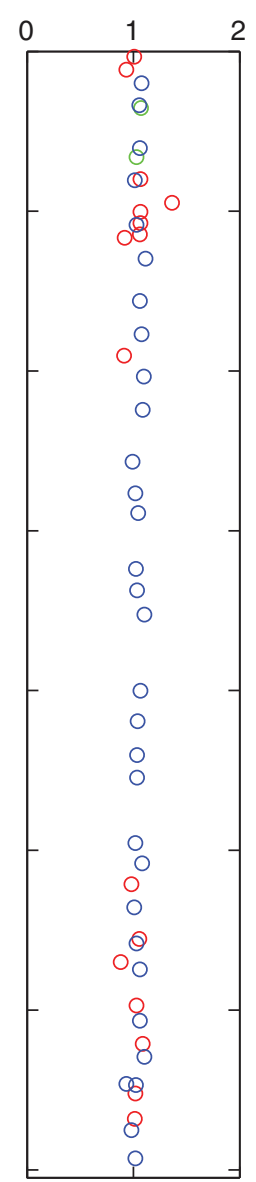

O $P$-wave $\mathrm{x}$ 
Figure F10. Temperature as a function of depth, Holes U1396A (blue) and U1396C (green). Straight line is a best fit to the measurements.

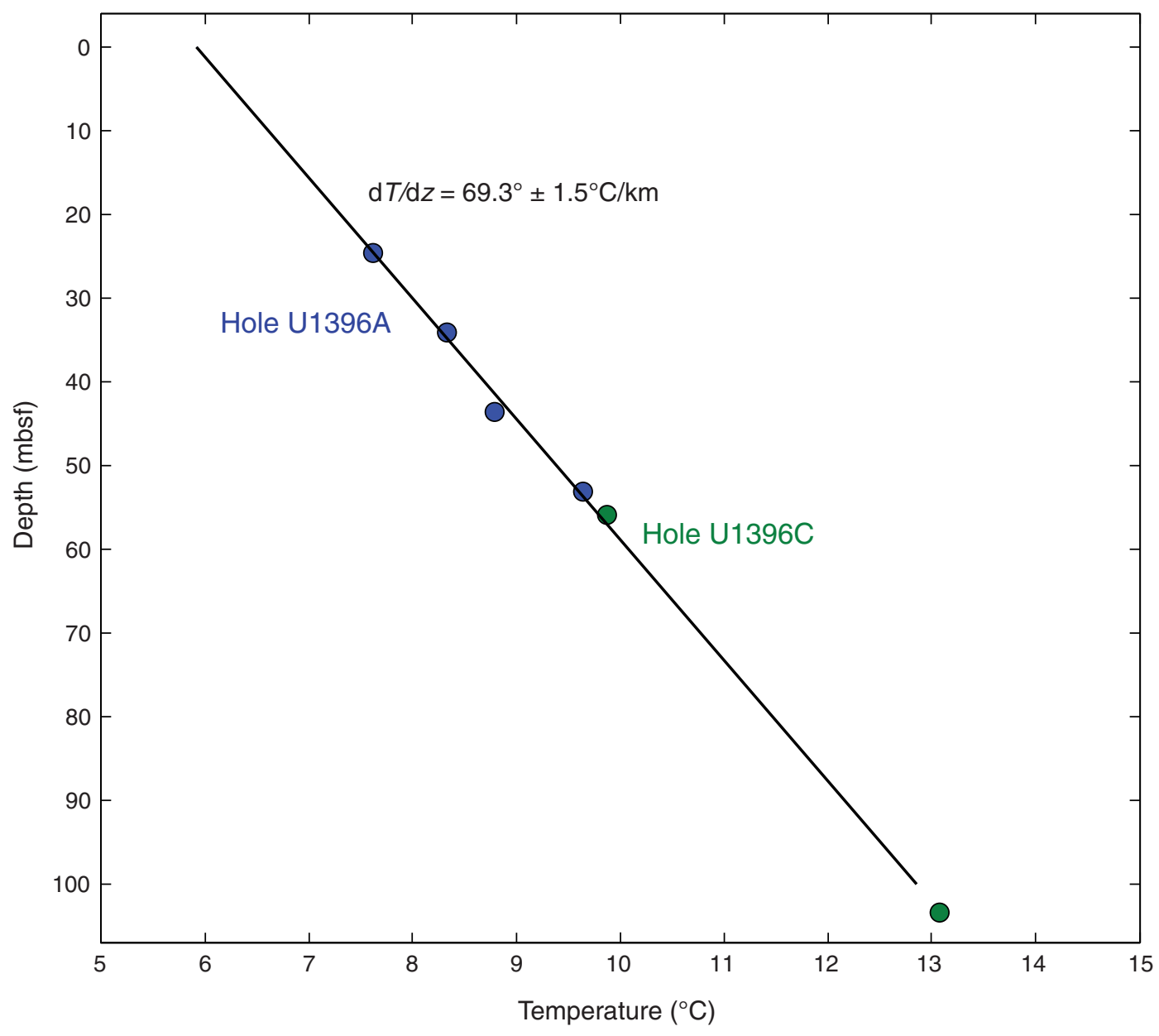


Figure F11. Plots of intensity of $\mathrm{NRM}_{0}$ (red) and $\mathrm{NRM}_{20}$ (blue) and inclination and declination after $20 \mathrm{mT}$ demagnetization, Holes U1396A and U1396B. Hole U1396B data (purple) is shown spliced into the Hole U1396A record. For directional data, red points show measurements made on cores recovered with nonmagnetic barrels and orange points denote the use of standard steel barrels. All red declination points are FlexIt tool-corrected to true north for the site $-15.6^{\circ} \mathrm{W}$; orange points are discrete inclination guided data (see text). Black squares are discrete inclination measurements shown against a geocentric axial dipole (GAD) inclination of $30.6^{\circ}$. The black and white "barcode" illustrates periods of normal (black) and reversed polarity (white) with calibrated ages from the GPTS of Cande and Kent (1995).

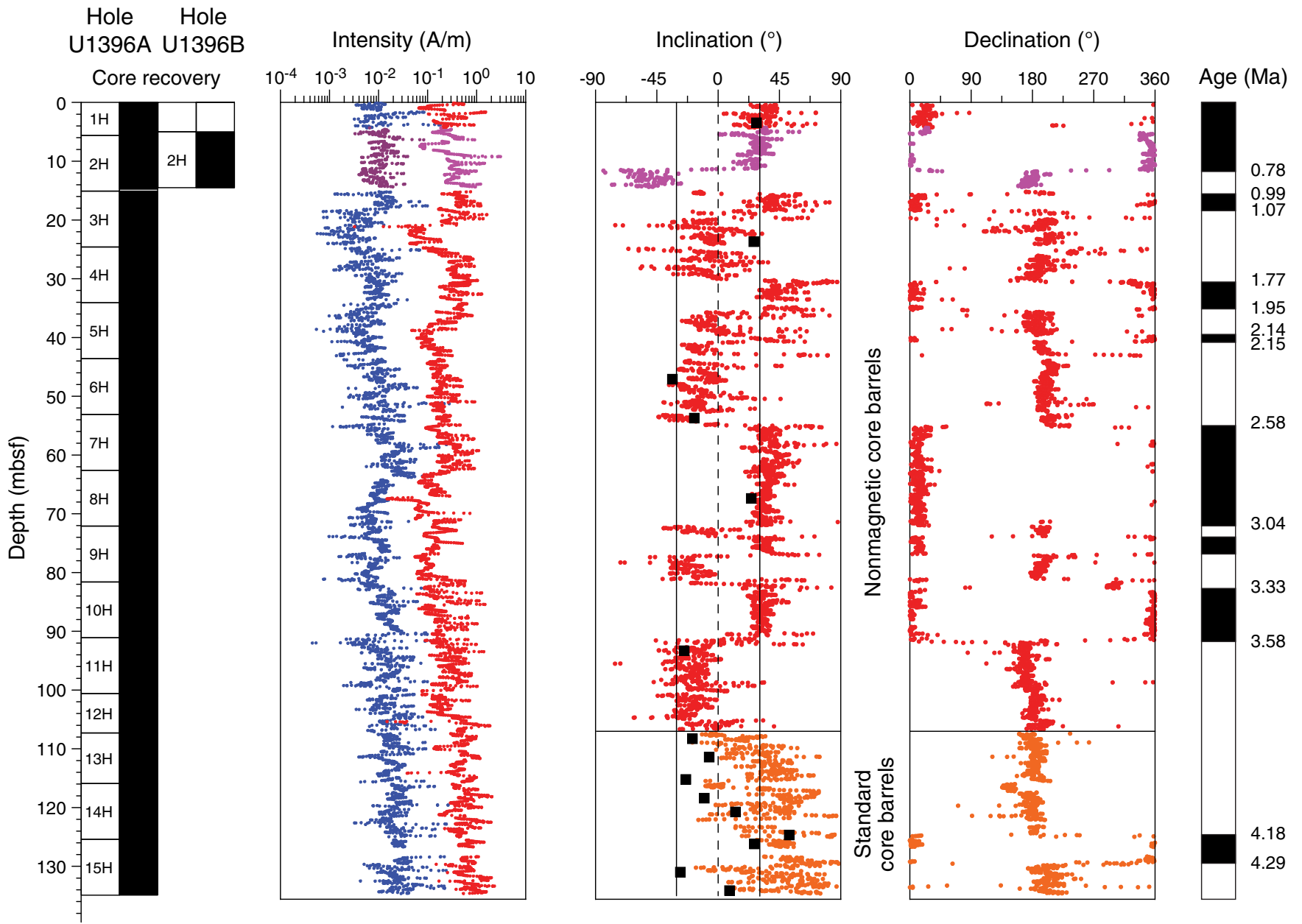


Figure F12. Plots of intensity of $\mathrm{NRM}_{0}$ (red) and $\mathrm{NRM}_{20}$ (blue) and inclination and declination after $20 \mathrm{mT}$ demagnetization, Hole U1396C. All declination points are FlexIt tool-corrected to true north for the site $-15.6^{\circ} \mathrm{W}$. Black squares are discrete inclination measurements shown against a geocentric axial dipole (GAD) inclination of $30.6^{\circ}$. The black and white "barcode" illustrates periods of normal (black) and reversed polarity (white) with calibrated ages from the GPTS of Cande and Kent (1995).

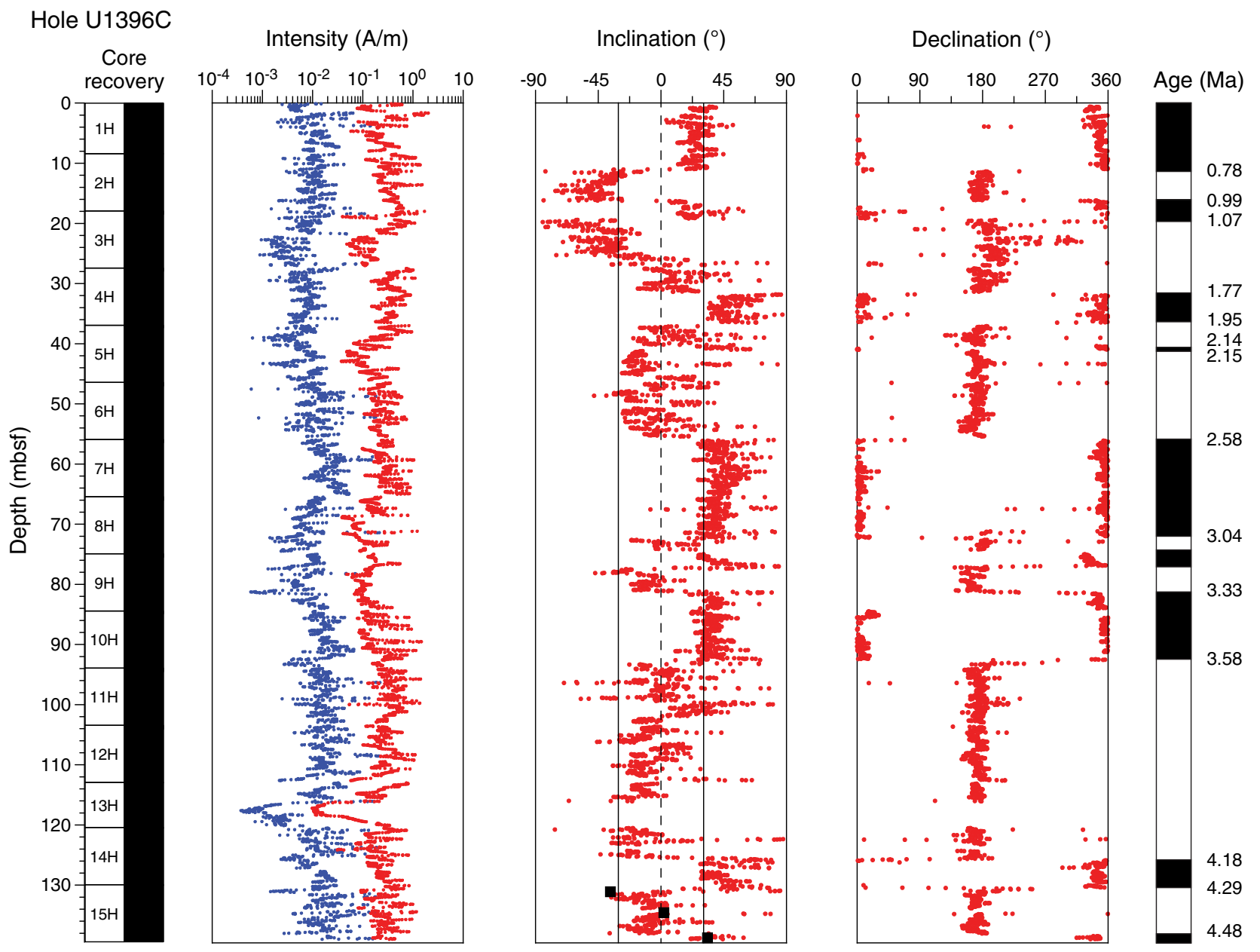


Figure F13. Magnetic susceptibility correlations used to transfer Hole U1396A depths onto Hole U1396C depths. The composite inclination record is shown on Hole U1396C.

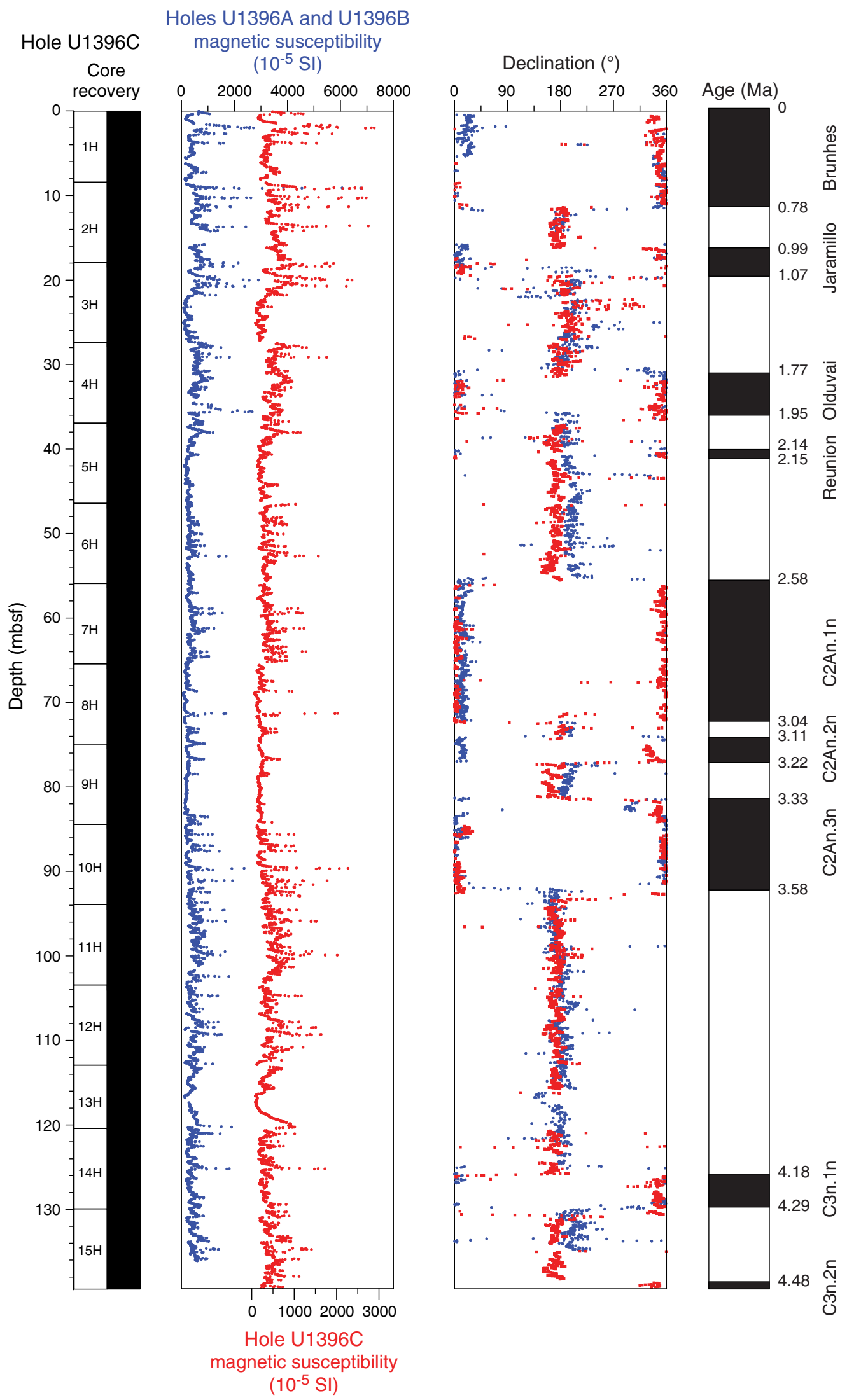


Figure F14. Age vs. depth, Hole U1396C. Reversal horizons are shown on the $y$-axis barcode diagram vs. the GPTS of Cande and Kent (1995) on the $x$-axis. Paleomagnetic directions compare well with biostratigraphic datums, which are split into nannofossil and planktonic foraminiferal datums.
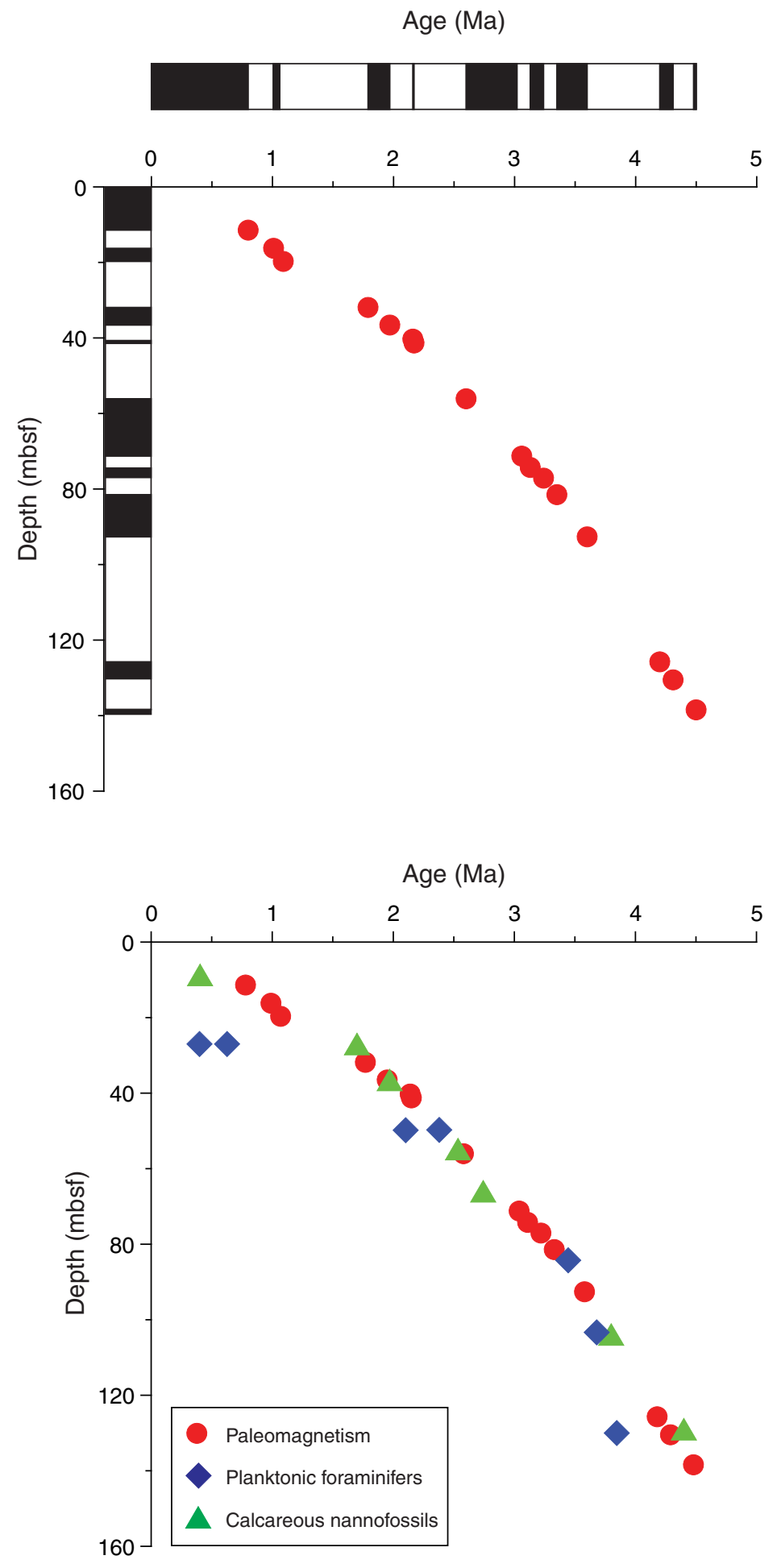
Table T1. Coring summary, Site U1396. (Continued on next page.)

\begin{tabular}{|c|c|}
\hline Hole: & U1396A \\
\hline Latitude: & $16^{\circ} 30.4841^{\prime} \mathrm{N}$ \\
\hline Longitude: & $62^{\circ} 27.1017^{\prime} \mathrm{W}$ \\
\hline Water depth (m): & 787.4 \\
\hline Date started (UTC*): & 1845 h 16 March 2012 \\
\hline Date finished (UTC*): & 1215 h 17 March 2012 \\
\hline Time on hole (days): & 0.7 \\
\hline Seafloor depth DRF $(\mathrm{m})$ : & 798.9 \\
\hline Penetration DSF (m): & 134.9 \\
\hline Cored interval (m): & 134.9 \\
\hline Recovered length (m): & 140.51 \\
\hline Recovery (\%): & 104 \\
\hline Total cores (no.): & 15 \\
\hline Hole: & U1396B \\
\hline Latitude: & $16^{\circ} 30.4847^{\prime} \mathrm{N}$ \\
\hline Longitude: & $62^{\circ} 27.0912^{\prime} \mathrm{W}$ \\
\hline Water depth (m): & 787.4 \\
\hline Date started (UTC*): & 1215 h 17 March 2012 \\
\hline Date finished (UTC*): & 1330 h 17 March 2012 \\
\hline Time on hole (days): & 0.01 \\
\hline Seafloor depth DRF $(m)$ : & 798.9 \\
\hline Penetration DSF $(\mathrm{m})$ : & 14.5 \\
\hline Cored interval $(\mathrm{m})$ : & 9.5 \\
\hline Recovered length (m): & 10 \\
\hline Recovery (\%): & 105 \\
\hline Drilled interval $(\mathrm{m})$ : & 5 \\
\hline Drilled interval (no.): & 1 \\
\hline Total cores (no.): & 1 \\
\hline Hole: & U1396C \\
\hline Latitude: & $16^{\circ} 30.4729^{\prime} \mathrm{N}$ \\
\hline Longitude: & $62^{\circ} 27.0905^{\prime} \mathrm{W}$ \\
\hline Water depth (m): & 786.6 \\
\hline Date started (UTC*): & 1330 h 17 March 2012 \\
\hline Date finished $\left(\right.$ UTC $\left.^{*}\right)$ : & 0530 h 18 March 2012 \\
\hline Time on hole (days): & 0.47 \\
\hline Seafloor depth DRF $(\mathrm{m})$ : & 798.1 \\
\hline Penetration DSF (m): & 139.4 \\
\hline Cored interval (m): & 139.4 \\
\hline Recovered length (m): & 145.92 \\
\hline Recovery (\%): & 105 \\
\hline Total cores (no.): & 15 \\
\hline
\end{tabular}

\begin{tabular}{|c|c|c|c|c|c|c|c|c|c|}
\hline Core & $\begin{array}{l}\text { Top depth } \\
\text { drilled } \\
\text { DSF (m) }\end{array}$ & $\begin{array}{c}\text { Bottom depth } \\
\text { drilled } \\
\text { DSF }(\mathrm{m})\end{array}$ & $\begin{array}{l}\text { Advanced } \\
(\mathrm{m})\end{array}$ & $\begin{array}{l}\text { Recovered } \\
\text { length } \\
(\mathrm{m})\end{array}$ & $\begin{array}{l}\text { Curated } \\
\text { length } \\
\text { (m) }\end{array}$ & $\begin{array}{l}\text { Top depth } \\
\text { cored } \\
\text { CSF }(m)\end{array}$ & $\begin{array}{l}\text { Bottom depth } \\
\text { recovered } \\
\text { CSF }(m)\end{array}$ & $\begin{array}{l}\text { Recovery } \\
\text { (\%) }\end{array}$ & $\begin{array}{l}\text { Time on deck } \\
\left(\text { UTC }^{*}\right)\end{array}$ \\
\hline \multicolumn{10}{|c|}{ 340-U1396A- } \\
\hline $1 \mathrm{H}$ & 0.0 & 5.6 & 5.6 & 5.63 & 5.63 & 0.0 & 5.63 & 101 & $3 / 17 / 12$ 07:45 \\
\hline $2 \mathrm{H}$ & 5.6 & 15.1 & 9.5 & 9.17 & 9.17 & 5.6 & 14.77 & 97 & $3 / 17 / 1208: 40$ \\
\hline $3 \mathrm{H}$ & 15.1 & 24.6 & 9.5 & 10.08 & 10.08 & 15.1 & 25.18 & 106 & $3 / 17 / 1209: 35$ \\
\hline $4 \mathrm{H}$ & 24.6 & 34.1 & 9.5 & 10.23 & 10.23 & 24.6 & 34.83 & 108 & $3 / 17 / 1210: 25$ \\
\hline $5 \mathrm{H}$ & 34.1 & 43.6 & 9.5 & 10.17 & 10.17 & 34.1 & 44.27 & 107 & $3 / 17 / 1211: 15$ \\
\hline $6 \mathrm{H}$ & 43.6 & 53.1 & 9.5 & 10.17 & 10.17 & 43.6 & 53.77 & 107 & $3 / 17 / 1212: 05$ \\
\hline $7 \mathrm{H}$ & 53.1 & 62.6 & 9.5 & 9.96 & 9.96 & 53.1 & 63.06 & 105 & $3 / 17 / 1212: 40$ \\
\hline $8 \mathrm{H}$ & 62.6 & 72.1 & 9.5 & 10.14 & 10.14 & 62.6 & 72.74 & 107 & $3 / 17 / 1213: 15$ \\
\hline $9 \mathrm{H}$ & 72.1 & 81.6 & 9.5 & 9.96 & 9.96 & 72.1 & 82.06 & 105 & $3 / 17 / 1213: 50$ \\
\hline $10 \mathrm{H}$ & 81.6 & 91.1 & 9.5 & 9.58 & 9.58 & 81.6 & 91.18 & 101 & $3 / 17 / 1214: 25$ \\
\hline $11 \mathrm{H}$ & 91.1 & 100.6 & 9.5 & 9.94 & 9.94 & 91.1 & 101.04 & 105 & $3 / 17 / 1214: 55$ \\
\hline $12 \mathrm{H}$ & 100.6 & 107.3 & 6.7 & 6.78 & 6.78 & 100.6 & 107.38 & 101 & $3 / 17 / 1215: 40$ \\
\hline $13 \mathrm{H}$ & 107.3 & 115.9 & 8.6 & 8.65 & 8.65 & 107.3 & 115.95 & 101 & $3 / 17 / 1216: 45$ \\
\hline $14 \mathrm{H}$ & 115.9 & 125.4 & 9.5 & 9.98 & 9.98 & 115.9 & 125.88 & 105 & $3 / 17 / 1217: 35$ \\
\hline $15 \mathrm{H}$ & 125.4 & 134.9 & 9.5 & 10.07 & 10.07 & 125.4 & 135.47 & 106 & $3 / 17 / 1218: 20$ \\
\hline \multicolumn{10}{|c|}{ 340-U1396B- } \\
\hline 11 & & & $\star * * * \star D$ & rilled from & to $5.0 \mathrm{mb}$ & $\mathrm{Sf}^{\star \star \star \star \star *}$ & & & $3 / 17 / 12$ 21:05 \\
\hline $2 \mathrm{H}$ & 5.0 & 14.5 & 9.5 & 10.00 & 10.00 & 5.0 & 15.00 & 105 & $3 / 17 / 12$ 21:20 \\
\hline \multicolumn{10}{|c|}{ 340-U1396C- } \\
\hline $1 \mathrm{H}$ & 0.0 & 8.4 & 8.4 & 8.39 & 8.39 & 0.0 & 8.39 & 100 & $3 / 17 / 12$ 22:15 \\
\hline $2 \mathrm{H}$ & 8.4 & 17.9 & 9.5 & 10.07 & 10.07 & 8.4 & 18.47 & 106 & $3 / 17 / 12$ 23:05 \\
\hline $3 \mathrm{H}$ & 17.9 & 27.4 & 9.5 & 10.02 & 10.02 & 17.9 & 27.92 & 105 & $3 / 17 / 12$ 23:45 \\
\hline $4 \mathrm{H}$ & 27.4 & 36.9 & 9.5 & 9.95 & 9.95 & 27.4 & 37.35 & 105 & $3 / 18 / 1200: 20$ \\
\hline
\end{tabular}


Table T1 (continued).

\begin{tabular}{|c|c|c|c|c|c|c|c|c|c|}
\hline Core & $\begin{array}{l}\text { Top depth } \\
\text { drilled } \\
\text { DSF (m) }\end{array}$ & $\begin{array}{l}\text { Bottom depth } \\
\text { drilled } \\
\text { DSF }(m)\end{array}$ & $\begin{array}{l}\text { Advanced } \\
(\mathrm{m})\end{array}$ & $\begin{array}{l}\text { Recovered } \\
\text { length } \\
(\mathrm{m})\end{array}$ & $\begin{array}{l}\text { Curated } \\
\text { length } \\
(\mathrm{m})\end{array}$ & $\begin{array}{l}\text { Top depth } \\
\text { cored } \\
\text { CSF }(m)\end{array}$ & $\begin{array}{l}\text { Bottom depth } \\
\text { recovered } \\
\text { CSF }(m)\end{array}$ & $\begin{array}{l}\text { Recovery } \\
\text { (\%) }\end{array}$ & $\begin{array}{l}\text { Time on deck } \\
\left(\text { UTC }^{*}\right)\end{array}$ \\
\hline $5 \mathrm{H}$ & 36.9 & 46.4 & 9.5 & 10.11 & 10.11 & 36.9 & 47.01 & 106 & $3 / 18 / 1200: 50$ \\
\hline $6 \mathrm{H}$ & 46.4 & 55.9 & 9.5 & 10.03 & 10.03 & 46.4 & 56.43 & 106 & $3 / 18 / 1201: 55$ \\
\hline $7 \mathrm{H}$ & 55.9 & 65.4 & 9.5 & 10.11 & 10.11 & 55.9 & 66.01 & 106 & $3 / 18 / 1202: 25$ \\
\hline $8 \mathrm{H}$ & 65.4 & 74.9 & 9.5 & 10.07 & 10.07 & 65.4 & 75.47 & 106 & $3 / 18 / 1203: 00$ \\
\hline $9 \mathrm{H}$ & 74.9 & 84.4 & 9.5 & 9.98 & 9.98 & 74.9 & 84.88 & 105 & $3 / 18 / 1203: 35$ \\
\hline $10 \mathrm{H}$ & 84.4 & 93.9 & 9.5 & 10.09 & 10.09 & 84.4 & 94.49 & 106 & $3 / 18 / 1204: 15$ \\
\hline $11 \mathrm{H}$ & 93.9 & 103.4 & 9.5 & 10.15 & 10.15 & 93.9 & 104.05 & 107 & $3 / 18 / 1205: 50$ \\
\hline $12 \mathrm{H}$ & 103.4 & 112.9 & 9.5 & 9.57 & 9.57 & 103.4 & 112.97 & 101 & $3 / 18 / 12$ 07:15 \\
\hline $13 \mathrm{H}$ & 112.9 & 120.4 & 7.5 & 7.59 & 7.59 & 112.9 & 120.49 & 101 & $3 / 18 / 12$ 07:50 \\
\hline $14 \mathrm{H}$ & 120.4 & 129.9 & 9.5 & 9.68 & 9.68 & 120.4 & 130.08 & 102 & $3 / 18 / 1208: 50$ \\
\hline \multirow[t]{2}{*}{$15 \mathrm{H}$} & 129.9 & 139.4 & 9.5 & 10.11 & 10.11 & 129.9 & 140.01 & 106 & $3 / 18 / 1209: 25$ \\
\hline & & Totals: & 288.8 & 296.43 & 296.43 & & & & \\
\hline
\end{tabular}

* = ship local time was Universal Time Coordinated (UTC) $-4 \mathrm{~h} . \mathrm{DRF}=$ drilling depth below rig floor, DSF = drilling depth below seafloor, CSF $=$ core depth below seafloor. $\mathrm{H}=$ advanced piston corer.

Table T2. Solid-phase geochemistry, Site U1396.

\begin{tabular}{|c|c|c|c|c|c|c|c|}
\hline \multirow{2}{*}{$\begin{array}{l}\text { Core, } \\
\text { section }\end{array}$} & \multicolumn{2}{|c|}{ Depth (mbsf) } & \multicolumn{4}{|c|}{ Carbon (wt\%) } & \multirow{2}{*}{$\begin{array}{l}\text { Nitroger } \\
\text { (wt\%) }\end{array}$} \\
\hline & Top & Bottom & $\mathrm{CaCO}_{3}$ & Inorganic & Total & Organic & \\
\hline \multicolumn{8}{|c|}{ 340-U1396A- } \\
\hline $1 \mathrm{H}-1$ & 0.77 & 0.78 & 58.79 & 7.05 & 7.92 & 0.87 & $\mathrm{BD}$ \\
\hline $1 \mathrm{H}-4$ & 5.28 & 5.29 & 56.17 & 6.74 & 7.46 & 0.73 & $\mathrm{BD}$ \\
\hline $3 \mathrm{H}-1$ & 16.30 & 16.31 & 42.08 & 5.05 & 5.56 & 0.51 & $\mathrm{BD}$ \\
\hline $3 \mathrm{H}-4$ & 20.60 & 20.61 & 61.40 & 7.36 & 8.21 & 0.85 & $B D$ \\
\hline $3 \mathrm{H}-6$ & 23.16 & 23.17 & 72.32 & 8.67 & 9.51 & 0.84 & 0.04 \\
\hline $4 \mathrm{H}-2$ & 26.73 & 26.74 & 31.84 & 3.82 & 4.16 & 0.34 & $B D$ \\
\hline $4 \mathrm{H}-4$ & 30.05 & 30.06 & 60.97 & 7.31 & 7.83 & 0.52 & $\mathrm{BD}$ \\
\hline $4 \mathrm{H}-6$ & 32.34 & 32.35 & 35.64 & 4.27 & 4.70 & 0.43 & $B D$ \\
\hline $5 \mathrm{H}-1$ & 34.61 & 34.62 & 14.08 & 1.69 & 1.71 & 0.02 & $\mathrm{BD}$ \\
\hline $5 \mathrm{H}-4$ & 39.47 & 39.48 & 72.57 & 8.70 & 9.71 & 1.01 & $B D$ \\
\hline $6 \mathrm{H}-2$ & 46.07 & 46.08 & 63.87 & 7.66 & 8.76 & 1.10 & 0.01 \\
\hline $6 \mathrm{H}-6$ & 52.12 & 52.13 & 58.12 & 6.97 & 7.77 & 0.80 & .01 \\
\hline $7 \mathrm{H}-2$ & 55.49 & 55.50 & 53.17 & 6.38 & 6.86 & 0.48 & 0.01 \\
\hline $7 \mathrm{H}-6$ & 61.29 & 61.30 & 28.19 & 3.38 & 3.65 & 0.27 & $\mathrm{BD}$ \\
\hline $8 \mathrm{H}-5$ & 69.52 & 69.53 & 67.84 & 8.13 & 8.98 & 0.85 & 0.01 \\
\hline $9 \mathrm{H}-2$ & 74.81 & 74.82 & 63.91 & 7.66 & 8.22 & 0.56 & 0.06 \\
\hline $9 \mathrm{H}-7$ & 81.64 & 81.65 & 56.11 & 6.73 & 7.56 & 0.83 & 0.02 \\
\hline $10 \mathrm{H}-1$ & 82.41 & 82.42 & 65.68 & 7.87 & 8.39 & 0.52 & 0.02 \\
\hline $10 \mathrm{H}-5$ & 88.30 & 88.31 & 58.84 & 7.06 & 7.44 & 0.38 & 0.03 \\
\hline $11 \mathrm{H}-1$ & 91.93 & 91.94 & 43.13 & 5.17 & 5.45 & 0.28 & 0.02 \\
\hline $11 \mathrm{H}-7$ & 100.49 & 100.50 & 31.61 & 3.79 & 3.98 & 0.19 & 0.01 \\
\hline $12 \mathrm{H}-1$ & 101.04 & 101.05 & 50.98 & 6.11 & 6.27 & 0.16 & 0.02 \\
\hline $12 \mathrm{H}-5$ & 106.62 & 106.63 & 12.27 & 1.47 & 1.47 & $\mathrm{BD}$ & 0.01 \\
\hline $13 \mathrm{H}-1$ & 107.77 & 107.78 & 33.97 & 4.07 & 4.41 & 0.34 & 0.02 \\
\hline $13 \mathrm{H}-5$ & 114.15 & 114.16 & 45.38 & 5.44 & 5.83 & 0.39 & 0.02 \\
\hline $14 \mathrm{H}-1$ & 116.85 & 116.86 & 42.87 & 5.14 & 5.42 & 0.28 & 0.01 \\
\hline $14 \mathrm{H}-6$ & 124.54 & 124.55 & 63.98 & 7.67 & 8.11 & 0.44 & 0.02 \\
\hline $15 \mathrm{H}-2$ & 127.95 & 127.96 & 51.46 & 6.17 & 6.51 & 0.34 & 0.02 \\
\hline $15 \mathrm{H}-6$ & 133.25 & 133.26 & 39.97 & 4.79 & 4.92 & 0.13 & 0.01 \\
\hline \multicolumn{8}{|l|}{$340-U 139$} \\
\hline $2 \mathrm{H}-3$ & 12.51 & 12.52 & 49.91 & 5.98 & 6.14 & 0.16 & 0.01 \\
\hline
\end{tabular}

$\mathrm{BD}=$ below detection, values reported as 0. 
Table T3. Composition of interstitial pore water, Hole U1396C.

\begin{tabular}{|c|c|c|c|c|c|c|c|c|c|c|c|c|c|c|c|c|c|c|}
\hline \multirow{2}{*}{$\begin{array}{l}\text { Core, } \\
\text { section }\end{array}$} & \multicolumn{2}{|c|}{ Depth (mbsf) } & \multirow{2}{*}{$\begin{array}{c}\text { Alkalinity } \\
(\mathrm{mM})\end{array}$} & \multirow[b]{2}{*}{$\mathrm{pH}$} & \multirow{2}{*}{$\begin{array}{c}\mathrm{Cl} \\
(\mathrm{mM})\end{array}$} & \multirow[b]{2}{*}{ \pm} & \multirow[b]{2}{*}{ Salinity } & \multirow{2}{*}{$\begin{array}{l}\mathrm{NH}_{4} \\
(\mathrm{mM})\end{array}$} & \multirow{2}{*}{$\begin{array}{c}\mathrm{Na} \\
(\mathrm{mM})\end{array}$} & \multirow[b]{2}{*}{ \pm} & \multirow{2}{*}{$\begin{array}{c}\mathrm{Mg} \\
(\mathrm{mM})\end{array}$} & \multirow[b]{2}{*}{ \pm} & \multirow{2}{*}{$\underset{(\mathrm{mM})}{\mathrm{K}}$} & \multirow[b]{2}{*}{ \pm} & \multirow{2}{*}{$\begin{array}{c}\mathrm{Ca} \\
(\mathrm{mM})\end{array}$} & \multirow[b]{2}{*}{ \pm} & \multirow{2}{*}{$\underset{(\mathrm{mM})}{\Sigma \mathrm{S}}$} & \multirow[b]{2}{*}{ \pm} \\
\hline & Top & Bottom & & & & & & & & & & & & & & & & \\
\hline \multicolumn{19}{|c|}{ 340-U1396C- } \\
\hline $1 \mathrm{H}-3$ & 4.40 & 4.50 & 1.99 & 7.40 & 567.5 & & 37 & 0.02 & 483.4 & 9.3 & 38.4 & 0.6 & 10.2 & 0.1 & 21.8 & 0.4 & 27.4 & 0.6 \\
\hline $2 \mathrm{H}-3$ & 12.80 & 12.90 & 1.16 & 7.26 & 574.2 & & 37 & 0.06 & 488.5 & 1.5 & 32.5 & 0.3 & 9.2 & 0.1 & 27.2 & 0.1 & 27.2 & 0.2 \\
\hline $2 \mathrm{H}-6$ & 17.30 & 17.40 & 1.43 & 7.25 & 576.1 & & 37 & 0.06 & 488.7 & 2.1 & 32.2 & 0.3 & 8.8 & 0.2 & 28.0 & 0.1 & 27.2 & 0.2 \\
\hline $3 \mathrm{H}-3$ & 22.20 & 22.30 & 1.21 & 7.16 & 574.4 & & 37 & 0.06 & 490.9 & 3.8 & 32.2 & 0.3 & 8.6 & 0.2 & 28.2 & 0.2 & 27.2 & 0.2 \\
\hline $3 \mathrm{H}-6$ & 26.80 & 26.90 & 1.28 & 7.13 & 579.4 & & 37 & 0.08 & 498.2 & 9.7 & 32.0 & 0.8 & 8.7 & 0.2 & 28.5 & 0.6 & 26.6 & 0.4 \\
\hline $4 \mathrm{H}-3$ & 31.80 & 31.90 & 1.35 & 7.16 & 575.9 & & 37 & 0.07 & 490.8 & 2.6 & 31.8 & 0.3 & 8.4 & 0.3 & 28.3 & 0.2 & 26.9 & 0.2 \\
\hline $4 H-5$ & 34.80 & 34.90 & 1.30 & 7.26 & 577.5 & & 37 & 0.07 & 492.1 & 4.3 & 32.0 & 0.3 & 8.3 & 0.0 & 28.4 & 0.3 & 26.8 & 0.1 \\
\hline $5 \mathrm{H}-4$ & 42.80 & 42.90 & 1.46 & 7.55 & 576.0 & & 38 & 0.09 & 491.3 & 2.4 & 31.4 & 0.3 & 8.5 & 0.3 & 28.1 & 0.1 & 26.7 & 0.2 \\
\hline $5 \mathrm{H}-6$ & 45.80 & 45.90 & 1.06 & 6.86 & 579.0 & & 37 & 0.07 & 485.6 & 3.4 & 31.4 & 0.3 & 8.2 & 0.3 & 28.1 & 0.2 & 26.7 & 0.3 \\
\hline $6 \mathrm{H}-3$ & 50.70 & 50.80 & 1.32 & 7.57 & 579.0 & & 37 & 0.08 & 486.8 & 4.3 & 31.5 & 0.5 & 8.2 & 0.3 & 28.5 & 0.2 & 26.7 & 0.3 \\
\hline $6 \mathrm{H}-6$ & 55.30 & 55.40 & 1.12 & 7.25 & 580.8 & & 38 & 0.07 & 484.7 & 3.2 & 31.3 & 0.3 & 8.5 & 0.2 & 28.2 & 0.2 & 26.6 & 0.2 \\
\hline $7 \mathrm{H}-3$ & 60.30 & 60.40 & 1.36 & 7.20 & 576.9 & & 38 & 0.06 & 486.7 & 1.5 & 31.7 & 0.3 & 8.1 & 0.1 & 28.7 & 0.1 & 26.7 & 0.3 \\
\hline $7 \mathrm{H}-6$ & 64.80 & 64.90 & 1.35 & 7.28 & 580.0 & & 38 & 0.06 & 486.8 & 3.2 & 31.6 & 0.3 & 8.3 & 0.2 & 28.5 & 0.3 & 26.7 & 0.3 \\
\hline $8 \mathrm{H}-3$ & 69.80 & 69.90 & 1.39 & 7.66 & 578.6 & & 37 & 0.07 & 488.0 & 2.1 & 31.3 & 0.3 & 8.4 & 0.3 & 28.4 & 0.1 & 26.6 & 0.3 \\
\hline $8 \mathrm{H}-6$ & 74.35 & 74.45 & 1.37 & 7.80 & 578.4 & & 38 & 0.07 & 491.1 & 2.1 & 31.4 & 0.2 & 8.3 & 0.0 & 28.6 & 0.0 & 26.4 & 0.3 \\
\hline $9 \mathrm{H}-3$ & 79.30 & 79.40 & 1.20 & 7.32 & 578.4 & & 37 & 0.05 & 486.6 & 2.1 & 31.6 & 0.3 & 8.3 & 0.1 & 28.5 & 0.1 & 26.6 & 0.2 \\
\hline $9 \mathrm{H}-5$ & 82.30 & 82.40 & 2.42 & 7.45 & 575.8 & & 38 & 0.06 & 488.0 & 2.8 & 31.5 & 0.3 & 8.2 & 0.2 & 28.5 & 0.2 & 26.7 & 0.3 \\
\hline $10 \mathrm{H}-3$ & 88.82 & 88.92 & 1.44 & 7.48 & 576.6 & & 37 & 0.06 & 489.4 & 3.1 & 31.9 & 0.3 & 8.1 & 0.3 & 28.8 & 0.2 & 26.9 & 0.2 \\
\hline $10 \mathrm{H}-6$ & 93.35 & 93.45 & 1.50 & 7.23 & 576.2 & & 37 & 0.05 & 492.5 & 3.0 & 32.3 & 0.4 & 7.9 & 0.1 & 29.1 & 0.3 & 27.0 & 0.4 \\
\hline $11 \mathrm{H}-3$ & 98.30 & 98.40 & 1.24 & 7.12 & 578.7 & & 37 & 0.06 & 491.3 & 5.3 & 31.9 & 0.5 & 8.3 & 0.1 & 28.5 & 0.3 & 26.8 & 0.2 \\
\hline $11 \mathrm{H}-6$ & 102.71 & 102.81 & 1.31 & 7.36 & 576.5 & & 38 & 0.06 & 487.1 & 3.6 & 31.7 & 0.3 & 8.1 & 0.1 & 28.4 & 0.2 & 26.4 & 0.3 \\
\hline $12 \mathrm{H}-3$ & 107.83 & 107.93 & 1.23 & 7.38 & 576.7 & & 38 & 0.05 & 502.5 & 0.5 & 32.9 & 0.5 & 8.5 & 0.2 & 29.5 & 0.2 & 27.5 & 0.9 \\
\hline $12 \mathrm{H}-6$ & 112.10 & 112.20 & 1.23 & 7.47 & 576.8 & & 37 & 0.06 & 487.7 & 1.6 & 31.9 & 0.3 & 8.2 & 0.2 & 28.2 & 0.1 & 26.8 & 0.3 \\
\hline $13 \mathrm{H}-2$ & 115.81 & 115.91 & 1.05 & 7.31 & 575.9 & & 37 & 0.06 & 494.7 & 5.9 & 32.6 & 0.2 & 8.3 & 0.2 & 28.9 & 0.3 & 26.9 & 0.0 \\
\hline $14 \mathrm{H}-5$ & 127.49 & 127.59 & 1.37 & 7.33 & 576.2 & & 37 & 0.07 & 488.3 & 3.4 & 32.9 & 0.3 & 8.0 & 0.5 & 28.0 & 0.1 & 27.0 & 0.2 \\
\hline $15 \mathrm{H}-3$ & 134.33 & 134.43 & 1.24 & 7.23 & 572.6 & 0.7 & 38 & 0.06 & 484.7 & 2.8 & 33.6 & 0.4 & 7.9 & 0.2 & 27.5 & 0.3 & 27.2 & 0.2 \\
\hline $15 \mathrm{H}-6$ & 138.80 & 138.90 & 1.25 & 7.41 & 573.3 & 0.1 & 37 & 0.06 & 489.5 & 11.7 & 33.6 & 0.2 & 8.0 & 0.3 & 27.6 & 0.5 & 27.0 & 0.0 \\
\hline
\end{tabular}

Uncertainties for $\mathrm{Cl}$ represent $\pm 1 \sigma$ based on repeat analyses. Shaded samples represent average values for $\mathrm{Na}, \mathrm{Mg}, \mathrm{K}, \mathrm{Ca}$, and $\Sigma \mathrm{S}$ (total sulfur) from duplicate analyses from separate runs. Samples in italics represent averages from within-run duplicates. 
Table T4. Correlation of Hole U1396A to Hole U1396C.

\begin{tabular}{|c|c|c|}
\hline $\begin{array}{l}\text { Hole U1396A } \\
\text { depth (mbsf) }\end{array}$ & $\begin{array}{l}\text { Hole U1396C } \\
\text { depth (mbsf) }\end{array}$ & $\begin{array}{l}\text { Difference } \\
\text { (m) }\end{array}$ \\
\hline 0.362 & 0.335 & -0.027 \\
\hline 1.929 & 2.002 & 0.072 \\
\hline 2.604 & 2.673 & 0.069 \\
\hline 3.779 & 3.793 & 0.014 \\
\hline 15.568 & 16.159 & 0.592 \\
\hline 16.841 & 17.499 & 0.658 \\
\hline 17.548 & 18.354 & 0.806 \\
\hline 19.070 & 19.953 & 0.884 \\
\hline 19.770 & 20.690 & 0.921 \\
\hline 20.845 & 21.745 & 0.900 \\
\hline 22.211 & 23.137 & 0.926 \\
\hline 23.641 & 24.555 & 0.915 \\
\hline 24.324 & 25.348 & 1.024 \\
\hline 26.635 & 27.754 & 1.119 \\
\hline 26.851 & 27.945 & 1.094 \\
\hline 27.535 & 28.714 & 1.179 \\
\hline 27.889 & 29.107 & 1.218 \\
\hline 29.416 & 30.726 & 1.310 \\
\hline 29.989 & 31.286 & 1.297 \\
\hline 31.800 & 32.659 & 0.859 \\
\hline 33.495 & 33.660 & 0.166 \\
\hline 34.331 & 34.705 & 0.373 \\
\hline 34.594 & 35.539 & 0.945 \\
\hline 35.375 & 35.886 & 0.510 \\
\hline 35.712 & 36.687 & 0.975 \\
\hline 36.683 & 36.988 & 0.305 \\
\hline 37.667 & 37.991 & 0.324 \\
\hline 38.755 & 39.199 & 0.444 \\
\hline 39.986 & 40.603 & 0.617 \\
\hline 40.496 & 40.875 & 0.379 \\
\hline 41.793 & 42.211 & 0.418 \\
\hline 44.884 & 44.207 & -0.677 \\
\hline 45.348 & 45.525 & 0.177 \\
\hline 47.976 & 48.036 & 0.060 \\
\hline 48.685 & 48.911 & 0.226 \\
\hline 52.364 & 52.594 & 0.230 \\
\hline 57.935 & 58.797 & 0.862 \\
\hline 58.417 & 59.330 & 0.913 \\
\hline 60.410 & 61.135 & 0.725 \\
\hline 60.775 & 61.484 & 0.709 \\
\hline 61.740 & 62.475 & 0.735 \\
\hline 63.096 & 63.897 & 0.801 \\
\hline 63.631 & 64.464 & 0.834 \\
\hline 65.633 & 65.948 & 0.315 \\
\hline 68.167 & 68.559 & 0.392 \\
\hline 70.829 & 71.184 & 0.356 \\
\hline
\end{tabular}

\begin{tabular}{|c|c|c|}
\hline $\begin{array}{l}\text { Hole U1396A } \\
\text { depth (mbsf) }\end{array}$ & $\begin{array}{l}\text { Hole U1396C } \\
\text { depth (mbsf) }\end{array}$ & $\begin{array}{l}\text { Difference } \\
(\mathrm{m})\end{array}$ \\
\hline 72.336 & 73.011 & 0.675 \\
\hline 72.730 & 73.413 & 0.683 \\
\hline 76.293 & 76.585 & 0.293 \\
\hline 84.469 & 85.062 & 0.594 \\
\hline 84.933 & 85.500 & 0.567 \\
\hline 86.274 & 86.826 & 0.552 \\
\hline 86.853 & 87.469 & 0.616 \\
\hline 89.012 & 89.493 & 0.480 \\
\hline 90.423 & 90.969 & 0.546 \\
\hline 91.635 & 92.309 & 0.674 \\
\hline 92.425 & 93.102 & 0.678 \\
\hline 93.618 & 94.428 & 0.811 \\
\hline 94.861 & 95.755 & 0.893 \\
\hline 96.064 & 96.917 & 0.853 \\
\hline 96.591 & 97.259 & 0.667 \\
\hline 98.059 & 98.831 & 0.772 \\
\hline 99.007 & 99.761 & 0.754 \\
\hline 100.030 & 100.745 & 0.716 \\
\hline 102.369 & 103.663 & 1.294 \\
\hline 103.241 & 104.574 & 1.333 \\
\hline 104.077 & 105.528 & 1.451 \\
\hline 106.079 & 107.664 & 1.585 \\
\hline 106.713 & 108.279 & 1.566 \\
\hline 107.863 & 109.127 & 1.264 \\
\hline 109.351 & 110.631 & 1.280 \\
\hline 109.921 & 111.178 & 1.257 \\
\hline 110.863 & 112.190 & 1.327 \\
\hline 112.761 & 113.161 & 0.399 \\
\hline 114.630 & 115.143 & 0.513 \\
\hline 114.947 & 115.471 & 0.525 \\
\hline 115.598 & 116.401 & 0.803 \\
\hline 117.258 & 120.079 & 2.822 \\
\hline 119.554 & 120.858 & 1.305 \\
\hline 120.895 & 121.816 & 0.921 \\
\hline 121.336 & 122.349 & 1.013 \\
\hline 122.920 & 123.785 & 0.864 \\
\hline 123.889 & 125.015 & 1.126 \\
\hline 124.849 & 126.150 & 1.301 \\
\hline 125.659 & 126.588 & 0.929 \\
\hline 126.839 & 127.941 & 1.102 \\
\hline 129.351 & 130.580 & 1.229 \\
\hline 130.135 & 131.428 & 1.293 \\
\hline 131.907 & 133.191 & 1.284 \\
\hline 133.335 & 134.535 & 1.200 \\
\hline 134.349 & 135.639 & 1.290 \\
\hline
\end{tabular}


Table T5. Correlation of Hole U1396B to Hole U1396C.

\begin{tabular}{ccc}
\hline $\begin{array}{c}\text { Hole U1396B } \\
\text { depth (mbsf) }\end{array}$ & $\begin{array}{c}\text { Hole U1396C } \\
\text { depth (mbsf) }\end{array}$ & $\begin{array}{c}\text { Difference } \\
(\mathrm{m})\end{array}$ \\
\hline 5.208 & 6.400 & 1.192 \\
5.389 & 6.659 & 1.270 \\
5.475 & 6.789 & 1.314 \\
5.665 & 7.273 & 1.608 \\
5.971 & 7.886 & 1.915 \\
7.771 & 9.084 & 1.313 \\
9.010 & 10.250 & 1.241 \\
10.111 & 11.055 & 0.944 \\
10.342 & 11.307 & 0.965 \\
10.647 & 11.733 & 1.087 \\
11.489 & 12.378 & 0.889 \\
12.332 & 13.461 & 1.129 \\
13.488 & 13.703 & 0.215 \\
13.620 & 13.768 & 0.148 \\
13.898 & 14.123 & 0.225 \\
\hline
\end{tabular}

Table T6. Samples measured for paleomagnetism, Site U1396.

\begin{tabular}{|c|c|c|}
\hline Core & $\begin{array}{l}\text { Measured } \\
(\mathrm{mT})\end{array}$ & $\begin{array}{c}\text { APC } \\
\text { core barrel }\end{array}$ \\
\hline \multicolumn{3}{|c|}{ 340-U1396A- } \\
\hline $1 \mathrm{H}$ & $0,10,20$ & Nonmagnetic \\
\hline $2 \mathrm{H}$ & No, liner shattered & Nonmagnetic \\
\hline $3 \mathrm{H}$ & $0,10,20$ & Nonmagnetic \\
\hline $4 \mathrm{H}$ & $0,10,20$ & Nonmagnetic \\
\hline $5 \mathrm{H}$ & $0,10,20$ & Nonmagnetic \\
\hline $6 \mathrm{H}$ & $0,10,20$ & Nonmagnetic \\
\hline $7 \mathrm{H}$ & $0,10,20$ & Nonmagnetic \\
\hline $8 \mathrm{H}$ & $0,10,20$ & Nonmagnetic \\
\hline $9 \mathrm{H}$ & $0,10,20$ & Nonmagnetic \\
\hline $10 \mathrm{H}$ & $0,10,20$ & Nonmagnetic \\
\hline $11 \mathrm{H}$ & $0,10,20$ & Nonmagnetic \\
\hline $12 \mathrm{H}$ & $0,10,20$ & Nonmagnetic \\
\hline $13 \mathrm{H}$ & $0,10,20$ & Standard \\
\hline $14 \mathrm{H}$ & $0,10,20$ & Standard \\
\hline $15 \mathrm{H}$ & $0,10,20$ & Standard \\
\hline \multicolumn{3}{|c|}{ 340-U1396B- } \\
\hline $2 \mathrm{H}$ & $0,10,20$ & Nonmagnetic \\
\hline \multicolumn{3}{|c|}{ 340-U1396C- } \\
\hline $1 \mathrm{H}$ & $0,10,20$ & Nonmagnetic \\
\hline $2 \mathrm{H}$ & $0,10,20$ & Nonmagnetic \\
\hline $3 \mathrm{H}$ & $0,10,20$ & Nonmagnetic \\
\hline $4 \mathrm{H}$ & $0,10,20$ & Nonmagnetic \\
\hline $5 \mathrm{H}$ & $0,10,20$ & Nonmagnetic \\
\hline $6 \mathrm{H}$ & $0,10,20$ & Nonmagnetic \\
\hline $7 \mathrm{H}$ & $0,10,20$ & Nonmagnetic \\
\hline $8 \mathrm{H}$ & $0,10,20$ & Nonmagnetic \\
\hline $9 \mathrm{H}$ & $0,10,20$ & Nonmagnetic \\
\hline $10 \mathrm{H}$ & $0,10,20$ & Nonmagnetic \\
\hline $11 \mathrm{H}$ & $0,10,20$ & Nonmagnetic \\
\hline $12 \mathrm{H}$ & $0,10,20$ & Nonmagnetic \\
\hline $13 \mathrm{H}$ & $0,10,20$ & Nonmagnetic \\
\hline $14 \mathrm{H}$ & $0,10,20$ & Nonmagnetic \\
\hline $15 \mathrm{H}$ & $0,10,20$ & Nonmagnetic \\
\hline
\end{tabular}

$\mathrm{APC}=$ advanced piston corer 